\title{
Aproximación biográfica y literaria a Antonio Marqués y Espejo (1762-1818)
}

\author{
A biographical and literary approach \\ to Antonio Marqués y Espejo (1762-1818) \\ Felipe Rodríguez Morín
}

Sociedad Española de Estudios del Siglo XVIII

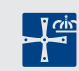




\section{RESUMEN}

Ante la gran escasez de datos sobre la vida del escritor y sacerdote ilustrado Antonio Marqués y Espejo, pretende el presente trabajo dar noticia de diversos sucesos de su existencia, para que puestos en conexión con sus publicaciones puedan contribuir a conocer, siquiera parcialmente, algo más de su persona, y de paso a añadir alguna luz sobre su obra, en mucha parte también desconocida. A este respecto, y en directa correlación con la anterior premisa, hemos querido aportar una imagen global de sus empresas literarias y, por lo mismo, necesariamente resumida, con el objetivo de tener una perspectiva panorámica de su obra y engranarla, así, con su biografía.

Palabras clave

Antonio Marqués y Espejo, vida y obra, traducciones del francés, ganancia económica, educación de la mujer, arrepentimiento, hospitalidad.

\section{AbSTRACT}

Due to the notable lack of information regarding the life of the Enlightenment writer and priest Antonio Marqués y Espejo, this essay aims to give news of several events of his existence, which, put in connection with his publications, will contribute to knowing, at least partially, something about him, and thus shedding some light on his work, quite unknown too. In this regard, and directly related to the previous premise, we have wanted to provide a global and therefore necessarily summarised image of his literary works, with the objective of having a panoramic perspective of his work, and connecting it with his biography.

KeY Words

Antonio Marqués y Espejo, life and work, translations from French, financial gain, women's education, remorse, hospitality.

Recibido: 3 de marzo de 2017. Aceptado: 5 de abril de 2017. 
Los muy escasos datos que hasta ahora se han barajado de la biografía de Antonio Marqués y Espejo procedían en lo sustancial de Juan Catalina García ${ }^{1}$. Es por tal motivo nuestro propósito contribuir ahora a rellenar modestamente algunas lagunas sobre su vida y a enlazar esta con su obra, sin pretender con ello componer una biografía exhaustiva sobre su persona, ni tampoco, desde luego, un estudio pormenorizado de su producción literaria.

\section{Primera época: los años de estudio}

Curiosamente, se hace necesario comenzar este trabajo contradiciendo al referido Juan Catalina, pues situaba la fecha de nacimiento de Marqués, acaecido en Gárgoles de Abajo, provincia de Guadalajara, en el día 11 de junio de 1762, cuando realmente tuvo lugar dicho suceso, si atendemos a su certificación de bautismo, el 27 de ese mismo mes y año, «como a las once de la noche ${ }^{2}$ ». El error de Catalina provenía sin duda de la mentada «Relación de los títulos [...]», que en su versión de 1785 indicaba esa fecha equivocada (en otro currículo posterior figuraba el día 7 de junio).

Fue su padre Josef Marqués Gómez, abogado de los Reales Consejos, doctor (suponemos que en Derecho), y durante mucho tiempo mayordomo de rentas del duque del Infantado en la villa de Pastrana, administrador de sus tercias reales en Zorita y Almoguera ${ }^{3}$, y alcalde mayor y juez de residencias

1 Juan Catalina García, Biblioteca de escritores de la provincia de Guadalajara y bibliografía de la misma hasta el siglo XIX, Madrid, Sucesores de Rivadeneyra, 1899. En el tomo I (págs. 301a-304b) aportaba Catalina diferentes noticias de Marqués, tanto de su biografía como de su obra escrita, y en el tomo II (pág. 580b) reseñaba una «Relación de los títulos, méritos, grados, ejercicios literarios y actos positivos del Doctor y Maestro D. Antonio Marqués y Espejo [...]», a la que más adelante nos referiremos.

2 Esta partida bautismal, extendida el 3 de julio, recoge como nombres del neófito los de «Antonio Cosme Isidro» (Archivo Diocesano de Sigüenza-Guadalajara, Parroquia de la Purísima Concepción de Gárgoles de Abajo, libro 2. ${ }^{\circ}$, f. 67r).

3 Ejerciendo este menester aparece en numerosos instrumentos notariales extendidos en Pastrana entre 1773 y 1780 — generalmente en obligaciones de pago a su favor por el grano que el duque fiaba a los labradores-, según atestiguan diversos documentos conservados en el Archivo Histórico de Protocolos de Guadalajara (a partir de ahora: AHPG), otorgados, bien ante el escribano Dionisio García Márquez: 37905, f. 3r y v, f. 40r y v, 37906, ff. 60r-61r, ff. 61r-62r, f. 114r y v, 157r y v, o bien ante el otro escribano de Pastrana, 
varias veces del referido grande de España, hasta rendir casi treinta años a su servicio ${ }^{4}$. Además de a Antonio, tuvo Josef con su esposa María Lorenza Espejo Isern — de la que tenemos constancia que no sabía firmar — otros siete hijos más. De tales hermanos de nuestro autor, sabemos de la existencia de Tadeo, abogado, como su padre, de los Reales Consejos, Fernando, teniente del Regimiento de Toro, Manuela, Josef ${ }^{6}$ y Ana; esta última, junto con Tadeo, acabarán por ser, tiempo después, los herederos de Antonio? ${ }^{7}$.

Ignoramos los años que residió la familia de Josef y M. ' Lorenza en Gárgoles de Abajo, pero de la documentación generada en la escribanía se colige, conforme hemos visto, que, como muy tarde, en el año 1773 se hallaba ya asentada en la villa de Pastrana. A primeros de octubre de 1776, comenzó Antonio Marqués, con catorce años de edad, sus estudios en la Universidad de Alcalá, según se extrae de la certificación de 17 de junio de 1777 del catedrático y presbítero Gabriel Gómez de la Torre, quien tras manifestar que dicho

Antonio Martínez Negre: AHPG, 37913, f. 19r y v, 64r y v, AHPG, 37914, protocolos de escrituras, de 1773, f. 19r y v, f. 64r y v, AHPG, 37914, de 1777, f. 31r y v, f. 32r y v, de 1780, f. 26r y v, 54r y v.

4 Así lo consigna el propio Antonio Marqués en una instancia dirigida al duque el 7 de setiembre de 1785, a la que luego volveremos a referirnos (Archivo Histórico Nacional, en adelante: AHN, Osuna, CT. 48134 , [s. n.]). Este es, además, el documento más antiguo que hemos encontrado en el que aparece el nombre y dos apellidos de nuestro autor, y lo hace en la firma, puesto que en el encabezamiento solo figura como «Antonio Marqués», al igual que en el resto de los anteriores escritos, en los que completaba su identificación con el apunte de que era natural de Gárgoles de Abajo; pues, al estilo de su padre, había firmado hasta entonces únicamente con el primer apellido. Ignoramos, por otro lado, la razón de que entre el primero y el segundo añadiera la conjunción «y», que ya luego quedaría para siempre.

5 En un poder otorgado por ella y por su marido en Pastrana el 2 de marzo de 1773, a favor de Josef Perales Beltrán, vecino de Alberique para que les administrase diferentes tierras plantadas de moreras y arrozal (AHPG, 37905, f. 44v), se puede leer lo que sigue: «firmó el que supo, y por la que no uno de los testigos». Igual ocurre unos años después, el 17 de octubre de 1777, en otro instrumento notarial, esta vez para que Josef Perales y Marqués, que debía ser hijo del anterior Josef Perales y, por tanto, sobrino de Josef Marqués, pudiera vender, cambiar y permutar las tierras y heredades que el matrimonio poseía en Sans (hoy Énova) y en Alberique (AHPG, 37906, ff. 200r-201v). Casi veinte años después, Antonio y su hermano Fernando volverán a la escribanía para asuntos relativos a estos mismos dominios, según luego veremos.

6 Las noticias de Manuela, bien indirectas, provienen del testamento, de 20 de agosto de 1776, de Teresa Chuanes Climent, quien se proclamaba (aunque los apellidos no coinciden) sobrina de Josef Marqués, y que según parece trabajó en la casa al servicio de su tío y de su esposa (AHPG, 37914, ff. 84r-85v). Por su parte, la única referencia a Josef Marqués y Espejo que poseemos la proporciona el librero Ramón Gómez Fuentenebro, efectuada en un determinado expediente sancionador relativo a la Retórica epistolar, en el que más adelante nos detendremos.

7 A partir de cierto documento notarial podría conocerse la identidad de otra hermana de Antonio, llamada Josefa, puesto que existe una declaración de pobre de una tal Josefa Marqués y Espejo, conjuntamente efectuada con su marido, Fernando Valladares. Y si bien la fecha puede parecer algo tardía: 21 de junio de 1848, dicho título fue extendido por el escribano, Justo de Sancha, acto seguido del expedido en los mismos términos para María Francisca Estévez, viuda del «teniente-capitán» Fernando Marqués y Espejo y cuñada de Antonio (Archivo Histórico de Protocolos de Madrid: AHPM, 25482, ff. 725r-726v, y ff. 723r-724v, respectivamente). 
alumno asistió a la asignatura de Súmulas y Lógica con puntualidad y aprovechamiento, estampaba la siguiente sentencia: «examinado y aprobado» ${ }^{\circ}$. El colegio mayor de San Ildefonso será durante aquellos años de estudios su residencia.

Con el final de curso de 1779 le fue concedido a Marqués el grado de bachiller, «in proclama Artium et Philosophie facultate obtinendo» ${ }^{9}$. E, igualmente, alcanzó el de maestro el 12 de enero de 1780, «Gradum Magisteri in Philosophia facultate» ${ }^{10}$. Sin pérdida de tiempo, comenzó a estudiar en la Academia de Teología Escolástica, y así, según se conserva en el mencionado expediente del AHN, consta de cada año, durante los cuatro de la carrera, el correspondiente certificado de asistencia y aprovechamiento: el primer curso en Lugares teológicos, y los tres siguientes en Teología, finalizando en todo ello el 12 de junio de 1783.

La solicitud de una beca que quedó libre nos permite en 1780 tener la primera noticia de que la economía familiar no era del todo boyante. A su instancia, fechada el 12 de junio, en la que mencionaba que reunía las condiciones requeridas para conseguir aquella, le acompañaba una certificación de su padre exponiendo que carecía de bienes y renta suficiente «para mantener en la carrera de Estudios a mi hijo Antonio», puesto que los cuatrocientos ducados anuales no le resultaban suficientes para sustentar «mis obligaciones y crecida Familia de ocho hijos» ${ }^{11}$. Igualmente, aportaba Antonio una certificación propia, con la misma data de 7 de junio, en la que, aparte de mencionar el hecho de que era el séptimo de ocho hermanos, juraba que carecía de rentas.

En muy similares términos, formuló Antonio Marqués una nueva petición el 17 de enero de 1783, para una de las cuatro becas vacantes en el colegio mayor de S. Ildefonso, adjuntando, como en la ocasión anterior, un papel de su progenitor (con la consiguiente validación del escribano), redactado un par de días antes en Pastrana, y en el que alegaba ahora que su hijo no gozaba de ninguna renta que llegara a doscientos ducados, "por cuyo motivo no le puedo mantener en la Universidad para el seguimiento de su Carrera Teológica». En

$8 \quad$ AHN, Universidades, 476-233, [s. n]. En parecidos términos, aunque ahora para la disciplina de Metafísica, el mismo Gabriel Gómez de la Torre le concedió el aprobado el 21 de junio de 1778, y en materia de Filosofía el 29 de octubre de 1779. Y es que Antonio figuraba en la lista de «Discípulos de D. Gabriel Gómez de la Torre», de 29 de junio de 1779 (AHN, Universidades, 409, f. 253r y v).

9 AHN, Universidades, 476-233.

10 AHN, Universidades, 409, f. 258v.

11 Este escrito paterno, dado en Pastrana en 7 de junio, aparece diligenciado por el notario de dicha localidad Martínez Negre, dando fe de la autenticidad de la firma de aquel y del empleo (al servicio del duque del Infantado) que había consignado (AHN, Universidades, 77-18, s. n.). 
la misma fecha que su padre, y firmando como «Maestro D. Antonio Marqués», ratificaba él mismo las palabras de su padre ${ }^{12}$.

Al concluir el curso de 1783, acudió a Valencia, en cuya Universidad le fueron incorporados los cuatro años de estudios en la referida Academia, concediéndosele el grado de bachiller en Sagrada Teología, «después de haber hecho los Ejercicios mandados por Real Cédula» ${ }^{13}$. Y concluido dicho examen, comenzaron los concernientes para alcanzar los grados de licenciado y doctor, «mereciendo la aprobación, que se le dio nemine discrepante por el Claustro de Teología de la misma Universidad de Valencia» ${ }^{14}$. Finalmente, el 13 de noviembre de 1783, según él mismo recoge en ese documento, y se comprueba en el Archivo de la Universidad de Valencia (en adelante AUV) ${ }^{15}$, alcanzó el título de doctor en Sacra Teología. Tras este logro, «asistió y ganó dos cursos de Teología Moral en la Academia pública de Santo Tomás de Aquino», donde además de cumplir con las pruebas pertinentes, «predicó siempre y cuando le correspondía en los años de ochenta y tres y ochenta y cuatro» ${ }^{16}$.

Asimismo, se apuntó a oposiciones, figurando su nombre en la «Lista de opositores a dos cátedras de Filosofía vacantes en la Universidad Literaria de la Ciudad de Valencia, en el año $1784 »^{17}$. Sin embargo, poco más adelante ${ }^{18}$ se revelaba que existían solicitantes que, a pesar de haber firmado y cumplido debidamente los requerimientos, no habían presentado justificación de sus méritos y ejercicios, entre los cuales se encontraba Antonio Marqués y Espejo ${ }^{19}$.

12 AHN, Universidades, 77-18. En AHN, Universidades, libro 1 140, ff. 59v y 73v, obran los respectivos asientos de su oposición a la beca en 1780 y en 1783. En esta segunda ocasión se le menciona como «Profesor de Teología».

13 Citamos ahora por un impreso de tres folios (s. n.), el mismo al que aludía Juan Catalina, y que Antonio encabezaba así: «Relación de los títulos, méritos, grados, ejercicios literarios y actos positivos del doctor y maestro Don Antonio Marqués y Espejo, del Gremio de Maestros de la Universidad de Alcalá de Henares, y Claustro de la de Valencia del Cid», con la constancia de que los documentos que avalaban los hechos descritos habían sido compulsados por el secretario de la Universidad de Alcalá de Henares el 5 de setiembre de 1785. Existe también otra enumeración más breve, impresa en un solo folio, con una denominación muy parecida a la anterior: «Títulos, méritos, grados [...]; del Claustro de Teología de la de Valencia, y Opositor a sus Cátedras», en la que sintetizaba sus logros académicos, si bien añadía al final: «Sigue firmando oposiciones» (ambas relaciones curriculares se conservan en AHN, Osuna, CT. 481-34).

14 AHN, Osuna, CT. 481-34.

15 AUV, libro 42, ff. 355v-357r.

16 AUV, libro 42, ff. 355v-357r.

17 AUV, libro 118, f. 82r.

18 AUV, libro 118, f. 93.

19 Consta igualmente esa condición de Antonio Marqués como opositor a la cátedra de Filosofía en el Archivo Histórico Municipal de Valencia (e-13, f. 100v). 


\section{Hacia la madurez: la paz del claustro y los tambores de guerra}

Con los estudios terminados y sin un empleo, la muerte de su padre, acaecida en 1785, supuso un duro golpe para la economía familiar. De ahí que fechada en Madrid el 7 de setiembre de ese año enviase Antonio una instancia al duque del Infantado, protector durante generaciones de su familia, solicitando una canonjía en la colegiata de Pastrana, de la que dicho grande de España era patrono único, «siendo los deseos del suplicante vivísimos hacia el estado sacerdotal $»^{20}$.

Unas cuantas semanas después, el día 26 de setiembre reiteraba esa misma petición su madre, quien la lleva a cabo desde el pueblo de San Felipe (hoy Játiva), posiblemente de forma simplemente nominal, pues, aunque su rúbrica figura estampada al pie del escrito, hemos de recordar que la mujer no sabía ni tan siquiera firmar. En dicho papel, mencionaba María Lorenza Espejo la circunstancia de que su hijo Antonio, al igual que sus hermanos mayores, se hallaban pensionados por el propio duque, y que otro de ellos, Tadeo Luis, ejercía de alcalde mayor en Escamilla, de los dominios del mismo señor. Sin embargo, esta solicitud no operó, desde luego, de forma instantánea, pues en su parte superior le fue añadido el siguiente rótulo: «Póngase con los demás pretendientes ${ }^{21}$.

Como el problema, lejos de solucionarse, parecía ir agravándose, se vio obligado de nuevo Antonio Marqués, residente por aquel entonces en Madrid, a remitir el 22 de febrero de 1786 una nueva súplica al referido aristócrata, con un tono de mayor desesperación esta vez. Confesaba en su misiva que, «hijo de una viuda a quien la necesidad conduce a la mayor miseria», había tenido que desprenderse de varias alhajas "para el preciso alimento», además de hallarse «vestido con harta indecencia»; y concretaba en esta ocasión su ruego en la concesión de una capellanía vacante en la misma colegiata de Pastrana. Pero, de semejante modo a lo ocurrido con la instancia de su madre, le fue estampada ahora a la suya la siguiente observación: «Inclúyasele en la Lista de los Pretendientes a la Capellanía vacante en Pastrana» ${ }^{22}$. Probablemente acompañaba Marqués estos sus escritos petitorios con la hoja de méritos anteriormente reseñada.

En idéntico legajo de la Sección de Nobleza del AHN se conserva también el testimonio de fray Antonio Miguel Yurami, quien, en contestación a un oficio

\footnotetext{
20 AHN, Osuna, CT. 581-34.

21 AHN, Osuna, CT. 481-34.

22 AHN, Osuna, CT. 481-34.
} 
del marqués de Santa Cruz, firmó en Madrid el 29 de abril de 1786 un escrito informando muy favorablemente acerca de Antonio Marqués. De este nos deja unas cuantas pinceladas sobre su personalidad, manifestando que desde el tiempo en que había asistido a su cátedra, en «el mes de Noviembre próximo pasado», había advertido en él «una inteligencia grande en las materias de las conferencias, grande pulso en sus resoluciones», «en su conducta hallo una docilidad y quietud que excede a su edad, y nada encuentro que desdiga del alto estado del Sacerdocio, a que aspira».

Otra fuente de información, igualmente de primera mano, relativa a la vida de nuestro autor la constituye un nuevo currículum, diez años posterior al otro ${ }^{23}$. Gracias a él nos es dado conocer que Antonio «cursó tres años la Sagrada Teología en el Seminario Conciliar de Santa Bárbara», sito en París, «con singular aplicación y aprovechamiento», «donde tomó todas las Órdenes, con dimisorias de su Obispo de Sigüenza» ${ }^{24}$. Las fechas y plazos manejados nos conducen a suponer que su entrada en el sacerdocio tuvo lugar, más o menos, a principios de 1789. Tras la cual retornó a España, pues sabemos que «en el año de mil setecientos ochenta y nueve tomó posesión de una Capellanía que tiene anexa la Cátedra de Latinidad de la Iglesia Colegial de Ampudia» ${ }^{25}$.

Y así en efecto hallamos que el cabildo de San Miguel y Abadía de Husillos, en la mencionada localidad palentina, le daba posesión el 10 de junio de 1789 de la capellanía vacante ${ }^{26}$, y aunque la misma figuraba como afecta

23 «Relación de los méritos, grados y ejercicios literarios del doctor Don Antonio Marqués y Espejo, Prebendado de la Iglesia Colegial de Ampudia, Capellán de la primera división de Granaderos Provinciales de Castilla la Vieja» (AHN, Osuna, CT. 482-4). Se trata de una copia testimoniada del original fechada el 6 de octubre de 1795, compuesta de tres folios sin numerar, en letra de imprenta, a los que sigue, como sucedía con el documento similar confeccionado en 1785, una hoja, igualmente en tamaño folio, en la que se encuentran condensados los hechos enumerados en la primera, aunque con la circunstancia de aportar algún que otro dato complementario; su título es ligeramente distinto: «Méritos literarios y militares del [...] Presbítero [...]». La conexión entre la figura de Marqués y Espejo y la documentación existente en este legajo del AHN, así como con la anteriormente indicada: AHN, Osuna, CT. 481-34, se la debemos a Ramón PAZ, cuando consigna el nombre de nuestro autor en el Índice de relaciones de méritos y servicios conservadas en la Sección de Consejos (Madrid, Archivo Histórico Nacional, 1943, n. ${ }^{\circ}$ 2579), si bien figura por anotación inserta a mano en el ejemplar que posee el propio AHN, por lo cual no aparece en el resto de los publicados.

24 Ignoramos la razón por la que el joven Marqués y Espejo se fue a estudiar a un seminario extranjero, pero tal vez se halle conectada con el hecho de que la familia ducal del Infantado residía por esa época en París. Con la Revolución francesa se mudó a un pueblo alemán, y no fue hasta la muerte del XII duque cuando retornó a España, en octubre de 1790. En una de sus traducciones del francés, Marqués confirmaba también su residencia en el país vecino: "poseo la facilidad de la elocución de los dos idiomas, porque habitante en ambas naciones, los he llegado a usar varios años» («Prólogo del traductor», en Recreos morales del ciudadano Hékel, Madrid, Mateo Repullés, 1803, págs. III-IV).

25 AHN, Osuna, CT. 482- 4.

26 Madrid, Imprenta de la Real Academia de la Lengua Española por los herederos de F. del Hierro 1734. 
a la enseñanza de Gramática, no desmiente ello la afirmación de Marqués si recordamos la definición de «Gramática» que recoge el Diccionario de autoridades, t. IV: «Por antonomasia se llama el estudio de la Lengua Latina ${ }^{27}$. La concesión de la plaza muy probablemente se debió a la mano protectora del duque del Infantado, patrono único de dicha iglesia, y cuyo apoderado general extendió título de presentación a favor de Marqués, que fue leído en voz alta por el secretario del cabildo. Como consecuencia de esa designación, se le confirieron a Antonio Marqués las funciones propias de su ministerio; de ahí que en el libro 251: «Libro de Registro para Licencias de Celebrar, Confesar y Predicar en la Abadía de Ampudia: desde el año de 1789», aparezca lo siguiente: «Misas. Dr. D. Antonio Marqués, licencia de Celebrar por 6 meses, en 26 de junio de 89» (f. lv). «D. Antonio Marqués, Capellán de esta Colegiata en (sustitución) 5 de febrero». Al margen: «Misa continuo para licencia verbal hasta 11 de Marzo de 91» (f. 2v).

El 14 de febrero de 1791 fue promovido a la plaza de racionero, igualmente con carta de presentación del duque del Infantado ${ }^{28}$. Consecuentemente, el anteriormente citado libro registral, $n .^{\circ} 251$, recoge el acontecimiento: «D. Antonio Marqués, Racionero de esta Colegiata, en once de Marzo de mil setecientos noventa y uno» (f. 4r). Y transcurridos doce meses «[p]rorroga la licencia de celebración D. Antonio Marqués por un año, contado desde el 13 de Marzo de 1792» (f. 5v). Es por eso que existe un error en su citada hoja de méritos, pues se pospone en ella un año su ascenso, ya que cuando habla allí de su paso por la capellanía de latín dice «que sirvió y desempeñó hasta el de mil setecientos noventa y dos, en que fue promovido a una Ración de la misma Iglesia que actualmente goza».

De otra parte, como con fecha 13 de marzo de 1793 se le iniciaba a Antonio una nueva prórroga de las licencias por un período de dos años (f. 6v), y la siguiente le fue otorgada el 24 de febrero de 1796 (f. 11r), quedaba de manifiesto una ruptura en la continuidad de las mismas, pues, como resulta notorio, la primera de ellas habría caducado en marzo de 1795. La causa de esta interrupción cobra su explicación de muy singular manera.

Conviene recordar, al efecto, que en marzo de 1793 España entró en conflicto bélico con la República francesa, en la que se denominó Guerra de la Convención, o del Rosellón, y en donde el XIII duque del Infantado, Pedro Alcántara Álvarez de Toledo y Salm-Salm, seis años más joven que Antonio, formó un

27 Archivo de la Iglesia Colegial de Ampudia (en adelante AICA, alojado en el Museo de Arte Sacro de dicho municipio), libro 244 de la parroquia de San Miguel y Abadía de Husillos de Ampudia, ff. 159v-160r.

28 AICA, libro 244, f. 220r. 
regimiento por él mismo comandado ${ }^{29}$. No sabemos si fue el aburrimiento de la vida en Ampudia ${ }^{30}$, o la llamada del deber a la patria y a su señor lo que empujó a nuestro racionero a ejercer su ministerio sacro, bajo las enseñas militares, como «Capellán del primer Batallón de la división de Granaderos Provinciales de Castilla la Vieja» ${ }^{31}$.

La «Relación de los méritos [...]» se hacía eco también de unas testimoniales del abad de la iglesia colegial de Ampudia, firmadas el 18 de marzo de 1793, en las que se expresaba la opinión que su superior tenía de Antonio Marqués, y cuya positiva valoración quizá le resultó imprescindible para ingresar en el ejército: «no está ligado con censura alguna, suspenso, ni procesado, antes bien es de buena vida y costumbres, hábil y benemérito para la obtención de Beneficios y Prebendas Eclesiásticas de las Iglesias de estos Reinos».

Pero antes de marchar a la contienda, en ese mismo 1793, dejó en la imprenta de Viuda e Hijos de Santander de Valladolid el manuscrito del primer libro suyo del que tenemos noticia: El perfecto orador ${ }^{32}$; un texto que ofrendó al duque del Infantado con una dedicatoria de seis páginas. Pretendía Marqués que su obra ayudase a la reforma de la predicación eclesiástica, simplificándola de muchos de los excesos en que se hallaba sumida desde el siglo anterior. Para ello, además de apoyarse en algunos códigos propios del teatro neoclásico, se valía del método de trasplantar textos de sermones de reputados clérigos franceses en ejemplificación de lo previamente expuesto de manera teórica ${ }^{33}$. Resultará así ese título el primero de muchos que reflejará la influencia de la cultura gala en su carrera literaria, fruto probablemente de aquellos tres años vividos en la capital francesa, y a la vez un adelanto de su prosa venidera, salpicada, por momentos, de galicismos.

29 Del Estado militar de España. Año de 1794 (Madrid, Imprenta Real, pág. 47), extractamos la siguiente información del Regimiento de Voluntarios de Castilla: «Fue creado [en el] año 1793. Consta de tres Batallones». «Coronel, el Duque del Infantado».

30 Justamente en el inicio del «Prólogo» de Blanca Capello, efectuará Marqués la siguiente confesión: «Encerrado por una política necesidad en un Pueblo de campos» (Madrid, Antonio Cruzado, 1803, [s. n.]).

31 AHN, Osuna, CT. 482-4.

32 Si bien con anterioridad habían aparecido dos libros en la estampa con las siglas «Dr. D. A. M.», coincidentes con las de Antonio Marqués: Avisos sobre la necesidad de retirarse a ejercicios y Examen crítico o influencia de la filosofía sobre las letras, ambos de la imprenta madrileña de González en 1788. González de Posada se los atribuye a Álvaro de Miranda Solís (Carlos González de Posada, Memorias históricas del Principado de Asturias y Obispado de Oviedo, Tarragona, Pedro Canals, 1794, t. I, págs. 253-254).

33 En su portada, aparte de sus títulos académicos, consignaba Marqués sus más recientes destinos: «Presbítero Seminarista en el de Clérigos de Santa Bárbara de París; Racionero de la Insigne Iglesia Colegial de Ampudia». Acerca de este libro puede consultarse: Felipe Rodríguez Morín, «El perfecto orador (1793) de Antonio Marqués y Espejo: la reforma de la predicación en España por medio de fuentes francesas», Cuadernos de Ilustración y Romanticismo, n. ${ }^{\circ} 23$ (2017), págs. 197-214. 
La campaña castrense de Antonio fue apurada hasta su final, acaecido en julio de 1795 con la Paz de Basilea. En su «Relación de los méritos» recuerda que sirvió en su mencionado empleo de capellán «en las campañas de mil setecientos noventa y tres, noventa y cuatro y noventa y cinco», «estando en la división del valle de Bastán» (sin duda se refiere a Baztán, en Navarra). Igualmente, se hace menester reseñar el hecho de que no pocas líneas del folio último de dicha «Relación» se destinan a describir diversos episodios acreditativos de su valor en el campo de batalla:

[D] esempeñando en cuantas ocasiones de armas allí ocurrieron, no solo las funciones propias de su ministerio, sino animando en medio del mayor riesgo a la tropa, lo que hizo distinguiéndose particularmente en los días seis de Junio de mil setecientos noventa y tres, en que atacó y fue rechazado el enemigo del Pueblo y alturas de Errazu: en cinco de Febrero de mil setecientos noventa y cuatro, en el ataque de Irún en los dos, tres y cuatro de Mayo del mismo, en que tomaron los enemigos Espegui y Bérderiz [probablemente los pasos de Ispegui y Berderiz]: en primero de Agosto del mismo año en la retirada de Irún, en que perdió su equipaje, ornamentos y vasos sagrados: y se portó muy señaladamente en los campos de Erice [Erice de Iza], donde atacó el enemigo en seis de Julio de este año de mil setecientos noventa y cinco, y con el mayor espíritu socorrió y auxilió indistintamente a los moribundos de ambos Ejércitos en medio del fuego.

Esta última hazaña sí que, de algún modo, pudo influir en su vida futura, ya que tal proeza le trajo aparejada una pensión del rey, según leemos a renglón seguido de lo anterior: «en cuya atención, habiéndole incluido el General en la relación que se dio a S. M. de estas operaciones, mandó en trece de julio último se le dé renta o Prebenda eclesiástica ${ }^{34}$. Y es que por pequeña que resultara la retribución económica de dicho beneficio, que acabó siéndolo sobre la mitra de Sevilla, figurará este estampado y lucido con orgullo en la portada de muchos de sus libros («Pensionado de S. M.»), y servirá, al final de sus días, para enjugar las deudas contraídas con su impresor y, tal vez, también editor, conforme más adelante veremos.

Después de concluidas las hostilidades parece que Antonio no pudo, o no quiso, volver de inmediato a Ampudia, sino que estuvo aún algún tiempo movilizado. Tal se deduce de lo expuesto en uno de sus libros, en el que con ocasión

34 No sabemos si la imparcialidad del general, probablemente el duque del Infantado, que acabó la guerra de brigadier, se vio afectada en estos puntos de heroísmo por la señalada relación de dependencia que de muy antiguo mantenía la familia de Marqués con la suya. 
de mencionar en él los montes Pirineos dice: «como buen vasallo, arrostré en ellos, por el espacio de cuatro años, los trabajos y riesgos padecidos en honor de nuestras banderas» ${ }^{35}$.

Por tal motivo probablemente no regresó a su colegiata hasta 1796, tal vez unos días antes de ese 24 de febrero en que, según registramos, le fue proporcionada la autorización para ejercer allí los correspondientes actos de culto. De su estancia y quehaceres como racionero en la iglesia de Ampudia no tenemos más noticias que las escasísimas proporcionadas por los documentos notariales otorgados por su cabildo ante el escribano de dicha localidad, Josef Tovar, quien recogía en el acta los nombres y empleos de los asistentes. Entre tales papeles de este fedatario aparece por primera vez Marqués el 9 de diciembre de 1791, y luego el 10 de enero de 1792. No figura, en cambio, en las certificaciones de 3 de agosto de 1793, ni de 15 de diciembre de 1794, como tampoco de 6 de noviembre de 1795, con la lógica explicación de que no había retornado todavía de la expedición bélica. Pero igualmente se halla ausente de esa relación de los miembros de la comunidad religiosa que extiende el mentado Tovar el 14 de diciembre de 1796, así como el 10 de febrero de 1797. Sí que se encuentra presente en otras fechas, como por ejemplo el 26 de noviembre de 1798, el 17 de marzo de 1799, el 31 de marzo de 1799, 14 de junio de 1799 y 12 de julio de 1799, última ocasión en la que encontramos su nombre. Aunque, probablemente, el documento notarial de mayor protagonismo para su persona fue el que el cabildo otorgó a su favor el 26 de septiembre de 1798, para que litigase en Paredes de Nava frente a dos arrendatarios que no pagaban ${ }^{36}$.

El tiempo de Marqués en la villa palentina se iba agotando, y así «[e]n 22 de Enero de 1801 vacó la Ración que tenía don Antonio Marqués y Espejo, por renuncia que este hizo, y le fue admitida por el M. I. Sr. Abad, como Juez ordinario $^{37}$ ». El 8 de marzo de 1801 tomará posesión de esa plaza Mateo González Velasco $^{38}$. Como suceso curioso, que no sabemos si tuvo relación de algún modo con la marcha de Marqués, hemos de reseñar que según se revela en otro de

35 Higiene política de la España, Madrid, Repullés, 1808, pág. 10.

36 Archivo Histórico de Palencia, Protocolos notariales de Ampudia, legajos 10650 (1788-1800)10651 (1801-1802). La condición de Marqués y Espejo como racionero en Ampudia también aparece recogida en la Guía del estado eclesiástico seglar y regular de España (Madrid, Imprenta Real), por ejemplo, en los años 1796 (pág. 181), 1797 (pág. 188), 1798 (pág. 196), padeciendo en todos los casos un error en su apellido, transcrito como «Marquez». La Guía informaba también sobre la composición de este cabildo: 1 abad mitrado, 4 dignidades, 12 canónigos, 8 racioneros y 8 capellanes.

37 A pesar de su partida a principios de 1801, su nombre todavía se mantuvo en la señalada Guía del estado eclesiástico correspondiente a 1802 (pág. 217), y además como 7. ${ }^{\circ}$ racionero, en lugar del 8. ${ }^{\circ}$ de años anteriores. Ya no aparece, en cambio, en la correspondiente al año 1803.

38 Ambos sucesos se hallan recogidos en: AICA, libro n. ${ }^{\circ} 253$, «Muertes, Ascensos y entradas de Prebendados y Capellanes», [s. n.]. 
los libros del archivo (n. ${ }^{\circ} 254$ ), en fecha 12 de enero de 1801 debía nuestro canónigo 800 reales a la fábrica de la iglesia (ff. 79r-80v).

\section{Madrid: un destino literario}

El rastro de Antonio Marqués se nos volverá a hacer visible a finales de ese 1801, en Madrid. Concretamente el 23 de diciembre, con motivo de un escrito del representante procesal del impresor Matías Repullés en solicitud de la licencia para imprimir el Diccionario feijoniano ${ }^{39}$. En dicho papel, aparte de referirse a la cualidad de presbítero de la persona de nuestro autor, y de dejar consignado que se hallaba pensionado por S. M., se apuntaba el empleo por él desempeñado entonces: «Capellán Colector de la Iglesia de Recogidas de esta Corte».

Pagaba Marqués con ese título — publicado en dos tomos, en Madrid, Imprenta de la calle de los Capellanes, 1802 - un tributo de admiración para con uno de los autores (el otro era Torres Villarroel) por los que patentizaba una especial deferencia: el P. Feijoo; un sentimiento del que deja testimonio también en varios lugares de su producción, como por ejemplo en la Retórica epistolar, en donde cita su nombre ya desde el propio arranque de la obra.

Consistió la idea de este libro en compendiar la ingente labor divulgativa del monje benedictino, presentándola de una forma fácil y asequible, a fin de conseguir el favor de un público mejor cuanto más numeroso ${ }^{40}$. Tal empresa se alzaba también como bandera por la que Marqués y Espejo se guiará, como buen hijo de la Ilustración, en su menester literario: la utilidad, salpimentada con el entretenimiento; pero ello realizado con un fin distinto a lo que pudiera resultar esperable, pues creemos que Marqués no contemplaba solamente el provecho del lector, sino que también y principalmente pretendía el suyo propio, procurando alcanzar una recaudación lo más amplia posible mediante la venta de sus libros. Por su parte, Álvarez de Miranda sintetiza su opinión acerca de este Dic-

39 AHN, Consejos, 5565-23. Su título completo es el de Diccionario feyjoniano, o compendio metódico de varios conocimientos críticos, eruditos y curiosos, utilísimos al pueblo para quien le dispuso, por orden alfabético. Consiguió la pertinente autorización para la imprenta, tras la censura positiva de junio de 1802; con ese fin, Repullés hará el pago de 60 reales en la Real Caja de Descuentos el 1 de julio de 1802.

40 Entre los suscriptores de la obra, según la lista que en ella se incluye, se encontraba alguna que otra persona principal, como por ejemplo el obispo de Cuenca, el teniente general Frey Antonio Filangiery, el conde de Altamira o el mariscal de campo marqués de Someruelos. Como simple curiosidad, hemos de señalar la circunstancia de que igualmente se hallaban suscritos a la obra un canónigo de la colegiata de Ampudia, su anterior destino, así como una monja adscrita al actual: «La Hermana María de la Concepción, Ministra de la Real casa de Recogidas de esta Corte», [s. n.].

El Diccionario feijonianio apareció anunciado en la Gaceta de Madrid de 28 de setiembre de 1802 (n. ${ }^{\circ}$ 79, pág. 976), donde se avisa, al paso, de la ampliación del plazo para la suscripción. 
cionario del siguiente modo: «obra de taracea consistente en coger de aquí y de allá párrafos de Feijoo y disponerlos según el orden alfabético de los temas: un ingenioso truco editorial que acerca más a Feijoo a la enciclopedia casera» ${ }^{41}$. "Sí señor, el de dar más extensión al conocimiento de las doctrinas de aquel grande sabio, facilitando su lectura por medio de ahorro de tiempo y dinero» ${ }^{42}$.

Resultó ser esta composición la cabeza de puente de su desembarco literario en la capital de España, una tarea de gigantes proporciones, bien que ello solo en lo que atañe a la cantidad ${ }^{43}$, que ya no tanto por lo que a la calidad concierne. Además, una parte de la misma seguramente la traía ya escrita de Ampudia ${ }^{44}$.

Como consecuencia de su nuevo destino de capellán en Madrid, muy probablemente vivió Antonio en la calle Hortaleza, pues por una Real Orden de 1750, según recoge Manuel Recio en 1777, se había dispuesto que el colector tuviese «casa contigua a la de las Hermanas Recogidas, para que pueda ocurrir con prontitud, en cualquier accidente que padezcan, de noche o de día, en que necesiten urgente espiritual socorro» ${ }^{45}$; previamente, había dejado anotado el lugar donde poseía una casa dicha institución: "Calle de Hortaleza, destinada para habitación de los Capellanes, Sacristán y Demandadero» ${ }^{46}$.

Recoge también Recio una costumbre de ese establecimiento que transcribimos íntegramente, pues consideramos que la majestad de la ceremonia y la conducta de arrepentimiento que comprendía el acto en sí, junto, por supuesto, con la propia labor de nuestro autor dentro de dicha fundación, inmersa en un ámbito femenino tan señaladamente infortunado, pudo tal vez repercutir en alguna medida en su obra futura:

41 Pedro Álvarez de Miranda, «Ensayo», en Francisco Aguilar Piñal (ed.), Historia literaria de España en el siglo XVIII, Madrid, CSIC, 1996, págs. 285-325, pág. 313, unas líneas antes había calificado a Antonio Marqués como «un experto en piratear libros».

42 Esta última cita pertenece al propio Marqués, quien salió a la tribuna del Diario de Madrid del 16 de enero de 1803 (n. ${ }^{\circ}$ 16, pág. 61) para dar su «Respuesta del autor del Diccionario Feijoniano a la carta de su impugnador, publicada en el Diario del 12 del presente mes».

43 Gullón Abao y Morgado García, hablando de Grasset, realizan la siguiente observación: «Esta dedicación a la poligrafía es muy frecuente en los autores finidieciochescos, que, debido a su precaria situación económica [...] debían estar continuamente publicando, pudiendo remitirnos a los casos de Restif de la Bretonne en Francia o de Pedro Estala y Antonio Marqués y Espejo en España» (Alberto GulLón Abao y Arturo Morgado García: «La imagen tópica de los habitantes del Pacifico a través de la Encyclopedie des voyages (1796) de Jacques Grasset Saint-Saveur», en Salvador Bernabéu Albert, Carmen Mena-García y Emilio José Luque Azcona (coords.), Conocer el Pacífico: exploraciones, imágenes y formación de sociedades oceánicas, Sevilla, Universidad de Sevilla, 2015, págs. 293-318, en red.

44 Por lo que atañe al Diccionario feijoniano, en una nota al pie de la penúltima página del «Prólogo del redactor» (s. n.), Marqués dice estar escribiendo ese preámbulo «en la Villa de Ampudia».

45 Manuel Recio, Compendio histórico y manifiesto instructivo del origen y fundación de la Real Casa de Santa María Magdalena de la Penitencia, vulgo las Recogidas de Madrid, Madrid, Joaquín Ibarra, 1777, pág. 146.

46 Recio, Compendio histórico, págs. 36-37. 
Mantiénese el santo instituto de esta fundación con tal observancia y vigor, que no se admite a ninguna mujer que no haya sido pública pecadora; y el acto de recepción es solemne, de grande ternura y edificación; pues el día señalado para la entrada de la Arrepentida en la Casa, se presenta vestida de gala en la sala de Juntas de la Hermandad; y formada esta, según acostumbra en sus actos públicos, se dirige a la Iglesia: en cuya puerta la recibe el Padre Espiritual con capa pluvial, y con sobrepellices el Capellán Colector de la Hermandad [de Nuestra Señora de la Esperanza], y los dos de la Casa con el Sacristán ${ }^{47}$.

Y es que, a la verdad, denota Antonio Marqués y Espejo, a partir de esa época, una especial sensibilidad hacia la mujer y su educación ${ }^{48}$, que se advierte, por ejemplo, en el Liceo General del Bello Sexo, revista que intentó publicar a este propósito, o en algunos de sus libros, cuya protagonista y título llevan nombre femenino (Blanca Capello, Miss Clara Harlowe, Matilde de Orleim, Anastasia, etc.). Un mundo que no asomaba, en cambio, en las dos obras precedentes citadas, ni tampoco en la siguiente: El aguador de París, en 1802, confeccionada, como el Diccionario feyjoniano, bien con anterioridad a la concesión de ese puesto, o bien cuando aún no llevaba en el mismo el tiempo suficiente como para haber quedado preso de su influjo.

No se puede dudar que el de 1802 fue un año sumamente fecundo para Antonio Marqués, puesto que, aparte de los dos últimos títulos, dará a la luz otros tres; como igualmente resultarán los años 1803 y 1804, en los que alumbrará otras nueve producciones más, algunas de varios tomos. A esa hiperactividad editorial quizá no fuera ajeno, en alguna medida, el hecho de que su hermano Fernando oficiase de librero en Madrid en la tienda de Fuentenebro en la calle de Carretas, al menos desde 1803.

Tornando a El aguador de París. Drama en prosa deducido de la ópera francesa Les deux jours, y a juzgar por las noticias de los periódicos, hallamos testimonio de su primera representación, acaecida el 17 de julio de 1802, en el Diario de Madrid de esa misma fecha (n. ${ }^{\circ}$ 199, pág. 794), así como de otras muchas repartidas a lo largo del año, siempre en el coliseo de los Caños del Peral, cuestión que acredita también la Gaceta de Madrid de 17 de diciembre

47 Recio, Compendio histórico, págs. 192-193. Mesoneros, por su parte, apuntaba algunas características de aquel lugar: «una vez entrado allí, no pueden salir más que para religiosas o casadas. Hay también una sala donde se guardan las mujeres a quienes sus parientes envían por castigo» (vid. Ramón de Mesonero Romanos, Manual de Madrid. Descripción de la Corte y de la Villa, Madrid, Imprenta de D. M. de Burgos, 1831, pág. 188). Sobre este particular, existe un libro impreso en 1786: Regla y constituciones de la Real Casa de Santa María de la Penitencia de las arrepentidas voluntarias (Madrid, Imprenta Real).

48 Cierto es que su admirado Feijoo había ya incidido en tales puntos, pero no con ese talante tan emotivo con que creemos que lo llevó a cabo Antonio Marqués. 
de 1802 (n. ${ }^{\circ} 102$, pág. 1256), a la vez que informaba de la venta del impreso, salido del taller de Antonio Cruzado, en la librería de Gómez Fuentenebro ${ }^{49}$. Su éxito en el escenario se extendió durante los años siguientes, conforme plasma la prensa madrileña de 1803, 1810, 1811, 1812 y 1813, y lo atestigua asimismo la autorización para volver a las tablas verificada en $1816^{50}$.

Otro gusto que descubrimos en el Marqués de este inicio de su periplo madrileño, postergado al cabo, tal vez por su corta valía en ese terreno, es el que toca a la lírica. Su arranque de forma pública en tal menester fue de forma tangencial, encajando una décima en honor de José Eustaquio Moreno Aguilar, gobernador del Consejo de Castilla, en el inicio del segundo tomo del Diccionario feijoniano, libro dedicado a dicho prócer ${ }^{51}$. Mejoró notablemente con su segundo proyecto poético, si bien de manera postiza, pues lo hizo editando dos creaciones de Cervantes: La Galatea y El viaje al Parnaso ${ }^{52}$. Para llegar, así, a los Desahogos líricos de Celio, dedicados al dios Apolo (Madrid, Repullés, 1802), una composición formada por todo un batiburrillo poético en el que tenían cabida romances, décimas, anacreónticas, redondillas, etc., sin un patrón definido, a la cual seguía un drama en verso: Las víctimas del libertinaje, que como apuntaba el Diario de Madrid de 8 de noviembre de 1802 (n. ${ }^{\circ} 321$, pág. 1258) - suponemos que transcribiendo de una minuta del autor-, complementaba la primera parte, encarrilándose su conjunto en aras del sempiterno afán de Marqués de inculcar enseñanzas con agrado:

[...] cuyo objeto no es otro que el de exponer a la vista de la juventud los daños de la pasión amorosa [...]; reúnen las dos circunstancias de instruir y deleitar, tanto por la variedad de metros contenida en la primera parte como con el colorido con que pinta el poeta en la segunda, que es un perfecto drama intitulado [...] la deformidad de una pasión.

49 Igualmente, el Diario de Madrid, calificándolo de «drama moral», había anunciado su venta unos días antes: el 29 de noviembre (n. ${ }^{\circ} 333$, pág. 1343).

50 A dicho año corresponde la licencia recogida por Francisco Aguilar Piñal en su imprescindible $B i$ bliografía de autores del siglo XVIII, Madrid, CSIC, t. V, 1989, pág. 428a, conservada en la Biblioteca Histórica Municipal de Madrid (BHMM), con la signatura 1-73-8. Consta también su representación en México entre los años 1805-1806 (vid. J. R. SpelL, «The Theater in Mexico City, 1805-1806», Hispanic Review, vol. 1, 1 (1933), págs. 55-65, más exactamente pág. 60). Para Cotarelo, sin embargo, la pieza se estrenó «con resultado mediano» (Emilio Cotarelo y Mori, Isidoro Máiquez y el teatro de su tiempo, Madrid, Publicaciones de la Asociación de Directores de Escena de España, 2009 (primera edición de 1902), pág. 189).

51 Aparte de otros cargos, además del ya mentado, José Eustaquio Moreno era protector de la institución a la que pertenecía Marqués: la Real Casa de Recogidas de Madrid.

52 En el mes de octubre de 1802 solicitó y obtuvo la consiguiente licencia para imprimir esos títulos (AHN, Consejos, 5565-28). El 16 de noviembre la Gaceta de Madrid (n. ${ }^{\circ} 93$, pág. 1 151) anunciaba la próxima venta de La Galatea en la librería de Fuentenebro. 
La sentencia de Cotarelo para con estos arrebatos líricos de Marqués no es de ningún modo benevolente, ya que lo tilda de "poetastro de aquel tiempo ${ }^{53}$. Sin embargo, sí que nos resulta ilustrativa esta concreta empresa suya desde dos puntos de vista. Por un lado, porque nos permite corroborar la devoción de Antonio por Torres Villarroel, mediante el simple título del proemio de los Desahogos: «Prólogo un poco a la violeta, con su dosis de los del astrólogo Torres; cuya ingenua claridad me ha gustado siempre, y sería utilísimo que agradara a todos». Y por otro, porque Marqués muestra precisamente ahí, en ese mismo preámbulo, repleto de sentido del humor, con una sinceridad que no asoma en ninguna otra parte de su obra, su afición por ganar dinero: «iDichoso yo, si con esta obra, me procuro algunos reales! Y venturoso tú, Lector benévolo si consigues un recreo útil de nuestras producciones» (pág. VII). Y, por si la cosa no había quedado suficientemente clara, nos revela más adelante que quiere rematar su «obrilla» con el siguiente epigrama: «No deseo que me aprecien, sino que me compren» (pág. XII). Ignoramos, de otra parte, si tuvo algo que ver con esta postura tan espontánea el hecho de que en la portada del libro únicamente apareciese, bajo el título, su nombre, sin alusión a su posición de sacerdote ni a otra circunstancia personal alguna.

No habría de terminar 1802 sin una nueva iniciativa literaria de nuestro capellán colector, en esta ocasión bastante más acorde con su condición de presbítero. Nos estamos refiriendo a la Antorcha mística, una traducción en seis tomos, en $8 .^{\circ}$, de la Lucerna mystica. Pro directoribus animarum, escrita en latín por José López Ezquerra en 1791. El Diario de Madrid de 16 de diciembre de 1802 (n. ${ }^{\circ} 350$, págs. 1410-1411) ofrecerá un amplio resumen, que por su redacción («nuestra traducción», «nos han animado») fácilmente se puede colegir que procede de la pluma de Marqués; el cual nos descubre, a la vez, la gran demanda que existía por producciones como aquella que presentaba

[...] los celosos esmeros con que es deseada de varios Reverendísimos Prelados, seculares y regulares, de comunidades religiosas de ambos sexos, de los Párrocos más venerables, de muchos señores Sacerdotes, dedicados al santo ministerio del confesonario, y no menos de infinitas almas que suspiran por el aumento de su espiritual perfección, nos han animado a esta trabajosa empresa, que concluida ya ofrecemos al bien común ${ }^{54}$.

53 Cotarelo y Mori, Isidoro Máiquez y el teatro, pág. 189.

54 Aunque de forma más breve, también la Gaceta de Madrid se hacía eco de esta publicación el día 31 de diciembre de 1802, n. ${ }^{\circ}$ 106, pág. 1296. 
Además, como el éxito comercial quedaba avalado en este caso específico por la multitud de reimpresiones de que había gozado la edición veneciana de 1761, de Remondi, no resultaría nada extraño suponer que, con su versión, Marqués pretendía alcanzar también jugosos beneficios económicos.

En 1803 dio Marqués a la estampa madrileña de Antonio Cruzado una novela: Memorias de Blanca Capello: Gran Duquesa de Toscana, para la historia de la virtud, en la humilde y alta fortuna, y aunque en el «Prólogo» insinuaba que la había sacado a partir del Nouveau dictionnaire historique, David Roas señala que se trata de una adaptación de Bianka Capello, de Augusto Gottlieb Meissner ${ }^{55}$. Pasó la solicitud de impresión por la censura sin dificultad ninguna, pues lo mismo el primer examinador, Juan Bautista de Ezpeleta, el 18 de diciembre de 1802, afirmando que el título contenía «la más sana moral y los documentos más juiciosos para dirigir la conducta de la juventud, con muy bello estilo y un lenguaje muy puro", como el segundo, Juan Antonio Pellicer, el 14 de febrero de 1803, que lo consideraba útil para los lectores, «por los buenos documentos que se esparcen en la obra, y por el desengaño que se puede sacar de la mudanza extraordinaria de los sucesos humanos ${ }^{56}{ }$, otorgaron gustosos el plácet para su puesta de molde ${ }^{57}$.

El objetivo de nuestro buen cura seguía siendo idéntico al que exponía para el tándem Desahogos líricos de Celio / Las víctimas del libertinaje, esto es: «Él es instructivo y útil. ¡Qué más que el precaver a los Jóvenes de ambos sexos de la facilidad con que suelen entregarse a los principios seductores de una pasión que les cautiva hasta perderles!» ${ }^{58}$, reafirmando así el subtítulo de la obra. Arremetía acto seguido contra los «rígidos zoilos de la erudición moderna, o los preocupados sabios de las edades godas», pero reconocía, a la par, el derecho del lector a criticar cumplidamente su obra y hasta juzgarla con severidad, puesto que la había pagado. Concluye, en este son, su preámbulo traduciendo unos versos de un satírico francés «Luego que por la impresión / el manuscrito se asoma, / de quien por su oro le toma / queda esclavo con razón».

Como se ve, no es poco el alcance que Marqués concedía al dinero, como nuevamente pone aquí de manifiesto. Y en buena avenencia con ello, empe-

55 David RoAs, Hoffmann en España. Recepción e influencias, Madrid, Biblioteca Nueva, 2002, pág. 80. La Gaceta de Madrid de 3 de mayo de 1803 (n. ${ }^{\circ}$ 35, pág. 368), parece querer recalcar la cualidad de inédita que se indicaba en el «Prólogo»: «obra nueva y original», si bien le antecedía una fórmula que permitía cualquier tipo de explicación: «recreo literario de D. Antonio Marqués y Espejo».

56 Pellicer incidía en el aspecto histórico de la narración: «aunque suena a Novela, no lo es en rigor, pues si bien el Autor suple mucho de su parte y añade no poco de su ingenio, pero la tela principal sobre que se teje su contexto es un caso y suceso verdadero, de que deponen varios Escritores».

57 AHN, Consejos, 5565-37, [s. n.].

58 «Pólogo», [s. n.]. 
zará con este libro la costumbre de estampar tras la portada de otros suyos la siguiente leyenda (posteriormente corregida en cuanto a que los femeninos «selladas» y «rubricadas» adoptarán el masculino, conforme les corresponde): «Este y los demás Ejemplares de cualquiera de las Obras de su Autor, irán selladas y rubricadas por él mismo». De este modo, personalizará sus frutos literarios y atraerá a más clientes mediante el moderno método, empleado aun en nuestros días, de firmar ejemplares. Todavía a la altura de 1818 existía constancia de su venta (Gaceta de Madrid, n. ${ }^{\circ}$ 90, 28 de julio de 1818, pág. 748).

Tampoco nació genuina de su péndola Recreos morales del ciudadano Hékel, sobre los asuntos más importantes al hombre, ya con anterioridad citada, sino que resultará otra traslación más del idioma francés, ahora de las Récréations morales, que J. M. Hékel había publicado en 1801. En el «Prólogo del traductor» Antonio Marqués, tras plantear una versión muy pesimista de las letras de su tiempo («la época más desgraciada para la literatura», pág. I), e intentar ganarse la indulgencia del lector mediante los manidos tópicos de mostrarse con modestia y glorificar la fuente, inimitable, de la que vierte al castellano su texto, aprovechó para tirarse a atacar, precisamente, a quienes reprobaban a los traductores: «jueces despóticos de idiomas que no entienden sin la penosa e insuficiente fatiga de sus Diccionarios» (pág. v). Una vez más la finalidad instructiva y el modo agradable de pintarla se erigirán en sus guías de conducta, pues versaba este trabajo suyo acerca de «las cuestiones más interesantes a la buena moral y al orden público [...], bajo la gustosa forma del diálogo, de la alegoría, del cuento, de un sueño, o de una ficción mitológica» (pág. III).

A dicho proemio de Marqués le precedía una «Nota del editor» (s. n.), probablemente de su propia mano, como treta para hacer ver que se había buscado al autor más idóneo para dicho propósito: «logré la satisfacción de verlos traducidos, a mi parecer, con la pureza y elegancia propia de la materia, del buen crédito del autor y de la dignidad del público». De paso, servía también para atraerse clientela elogiando la calidad del producto: "para la traducción como para la impresión no se ha escaseado gasto, a fin de que saliesen en todas sus partes con la perfección y hermosura posible ${ }^{59}{ }$. El 7 de junio de 1803 (n. ${ }^{\circ} 45$, pág. 476) fue anunciada en la Gaceta de Madrid, y aún en ese mismo periódico el 18 de febrero de 1815 (n. ${ }^{\circ} 21$, pág. 184), aunque con el título algo desfigurado Recursos morales del ciudadano Hokel.

59 Este aviso introductorio logró el 13 de mayo de 1803 la autorización, con la firma de Fuerte-Híjar, para poderse imprimir con la obra en sí, según consta en AHN, Consejos, 50 748, donde se conserva un manuscrito de la misma. 
Con pocos días de diferencia, la prensa de la capital de España dará noticia de otro título de Marqués, la Retórica epistolar, o Arte nuevo de escribir todo género de cartas misivas y familiares, con ejemplos de los autores más célebres, extranjeros y nacionales, caso de la Gaceta de Madrid de 17 de junio de 1803 (n. ${ }^{\circ} 48$, pág. 512). Nos hallamos ahora, sin disputa alguna, ante el mayor éxito editorial de Marqués y Espejo; una obra que gozó a lo largo de su historia de una muchedumbre de reediciones, hasta llegar a la última, de Marcial Pons, en $2001^{60}$. La sencillez y utilidad ${ }^{61}$ son sus divisas, y el origen («escribir cartas con acierto») una necesidad:

He notado, desde muy joven, que es muy expuesto el no saberla manejar [la pluma] con algún arte, y que contribuye ella mucho al bien o mal que nos procuramos. Por desgracia, no hallé en la edad en que más la necesitaba obra alguna semejante, que supliese a mi falta de experiencia, ni creo la tengamos hasta ahora. $(«$ Prefacio», s. n.)

A pesar de todas estas mieles, no comenzó con buen pie el libro, pues tuvo al poco de nacer cierto tropiezo con el Consejo de Castilla. En las actuaciones seguidas por esa causa ${ }^{62}$, consta una «Nota», de 27 de junio de 1803 , con motivo de no haberse entregado un ejemplar de la obra al gobernador del Consejo, por lo que hizo este patente «la necesidad de tomar providencia que sirva de escarmiento a los autores y libreros, y para contener los abusos y fraudes que en esto se experimentan, y las quejas de los censores por dárseles el ejemplar que como tales les corresponde».

Al día siguiente, 28 de junio, acudió un mandatario del Consejo a la librería de Ramón Gómez Fuentenebro en la calle Carretas y, tras exhibir este último la licencia para su publicación y venta, dijo «que el citado libro lo vende por comisión de Dn. Josef Marqués y Espejo», a quien suponía que habría puesto el original junto con el resto de ejemplares en la escribanía de gobierno del Consejo. Esta manifestación acarreó el que fueran embargados «todos los ejemplares de dicha obra, sin vender ninguno hasta que otra cosa se mande por el Consejo», y acto seguido: «Incontinenti. Yo, el escribano hice igual re-

60 A tal efecto, puede consultarse: Rosa María Aradra Sánchez, De la retórica a la teoría de la literatura (siglos XVIII y XIX), Murcia, Universidad de Murcia, 1997, pág. 209.

${ }_{61}$ Ana Rueda, que dedica a este trabajo de Marqués varias páginas (en especial: 143-147) de Cartas sin lacrar. La novela epistolar y la España Ilustrada, 1789-1840 (Madrid, Iberoamericana-Vervuert, 2001), afirma lo siguiente: «la Retórica Epistolar tiene un propósito utilitario, no filosófico» (pág. 147).

62 AHN, Consejos, 5566-12. 
querimiento al Librero Dn. Fernando Marqués y Espejo, hermano del Autor de la obra, en su persona».

Sin pérdida de tiempo, el mismo 28 de junio, Fernando Marqués elevó un escrito para explicar que el día 16 de junio, después de presentado un ejemplar en la Real Biblioteca «el Autor de dicha obra la puso de comisión para su venta, padeciendo la equivocación de que los ejemplares correspondientes a la secretaría de gobierno se habían puesto ya en ella por la persona a quien lo encargó, por cuya falta procede el mencionado y justo Decreto de V. Excma.». $\mathrm{Y}$ terminaba rogando «mirar con bondad en este caso a ambos Libreros, que de ningún modo ha procedido de mala fe, la que tampoco se halla en el Autor», a la par que solicitaba la entrega de los ejemplares retenidos. El día 1 de julio se despachaba resolución, en fin, accediendo a la anterior petición, con la advertencia de que en lo sucesivo para vender cualquier libro debía contar este con el recibo o certificación de que se habían entregado los ejemplares precisos en la escribanía de gobierno.

A pesar de que este título posee muchos elementos originales de Marqués y Espejo, creemos que se apoyó para su confección en, al menos, dos fuentes francesas. Por un lado, en la Rhetorique de l'honnête homme, ou la maniere de bien écrire des lettres, obra póstuma de Paul Colomiès (impresa en Amsterdam por George Gallet en 1799), que le sirvió de inspiración y que, en ocasiones, sigue muy de cerca, como en el caso de las cartas de pésame o en el inicio del capítulo II de Marqués en relación con el primero de Colomiès. Además, estimamos que el autor español se valió también de L'Art Épistolaire de Jauffret ${ }^{63}$, traduciendo de su tomo primero para la parte teórica, y del tercero para determinados modelos de cartas.

Por otra parte, y en consonancia con ese reconocimiento por parte de Marqués hacia el universo de la mujer, Sánchez Espinosa subraya el hecho de que en la Retórica epistolar se incluyen más modelos escritos por autoras reconocidas y personajes femeninos que, por ejemplo, en el Nuevo estilo y formulario de escribir cartas misivas, de J. Antonio D. Begas, «en correspondencia con un mayor protagonismo social de la mujer» ${ }^{64}$.

${ }^{63}$ André Jauffret, L'Art Épistolaire, ou Dialogues sur la manière de bien écrire les Lettres, París, Le Clere, 1800.

64 Gabriel Sánchez Espinosa, «Madame de Sévigné y la carta familiar en España durante el siglo XviII», en Mercedes Boixerau y Roland Desné (dirs.), Recepción de autores franceses de la época clásica en los siglos XVIII y XIX en España y en el extranjero, Madrid, UNED, 2001, págs. 111-123, (págs. 122-123), en red. Poco antes, el mismo Sánchez Espinosa había apuntado lo siguiente sobre la Retórica epistolar: «El manual de Marqués, conservando las situaciones epistolares de los manuales del tipo Nuevo [estilo y] formulario, coloca bajo estos epígrafes tanto preceptos y consideraciones didácticas, como modelos de autores reconocidos» (pág. 121). 
No habría de concluir el año 1803 sin que Marqués ofreciera al público otras dos nuevas traducciones del francés: Matilde de Orleim ${ }^{65}$ y la Historia de los naufragios. En cuanto a la primera de ellas, la pieza de teatro, se revela la misma como una traslación al castellano de la Mathilde de Monvel ${ }^{66}$, que en irónica síntesis de Cotarelo se correspondía con «un drama alemán del género sentimental, cuyo enredo estriba en un error que fácilmente puede desvanecer uno de los personajes, como lo anuncia casi al principio y, sin embargo, la opresión y desgracia de la virtud y de la inocencia se prolongan durante los cinco actos de reglamento» ${ }^{67}$. Esta obra, que fue escenificada en los Caños del Peral, no debe ser confundida con la homónima de Gaspar Zavala y Zamora, en tres actos y verso ${ }^{68}$. La Gaceta de Madrid de 25 de octubre de 1803 (n. ${ }^{\circ} 86$, pág. 932) registraba su venta en las librerías, y no solo en las de Madrid, pues remitía a otros puntos de adquisición en Sevilla, Segovia y Málaga ${ }^{69}$.

Por lo que atañe a la Historia de los naufragios, ha de significarse que fue puesta a la venta, antes que en volúmenes completos, en cuadernos, hasta un total de quince, que a razón de tres por cada tomo completaban los cinco de que constaba la colección. Salió el primero de ellos a finales de junio de 1803, y el último en marzo de $1804^{70}$. Excepto en dos de ellos, Marqués tradujo, recortando cuanto le pareció, de la Histoire des naufrages, de Deperthes ${ }^{71}$. En su perenne propósito de atraer al lector, presentaba con ese título un tema, cual el de las aventuras en el mar, muy de moda desde la aparición del Robinson Crusoe; ofreciendo, además, desde el «Prefacio» ofertas económicas para comprar la obra, a la par que se ocupaba de resaltar la cualidad tan perseguida del prodesse et delectare a través, por ejemplo, de las «Cortas reflexiones del editor» con que concluye el tomo III, donde intentaba convencer a los lectores de que perseguía la mejor opción para ellos, aun a costa del perjuicio propio (pág. 379). Como argucia magistral para captar la atención del destinatario y mantenerlo fiel durante sus cinco tomos, se erigió la inclusión en el primero de ellos de un

65 El autor no esconde el origen galo de su versión, pues recoge este punto en el subtítulo: «Drama en cinco actos y en prosa. Acomodado a nuestro teatro del francés, Madrid, Imprenta de la calle de Capellanes, 1803.

66 Boutet de Monvel, Mathilde. Drame en prose et en cinq actes, París, Hautbout-Dumoulin, 1799.

67 Cotarelo y Mori, Isidoro Máiquez y el teatro, pág. 204.

68 La referencia proporcionada por Aguilar Piñal en su citada Bibliografía (pág. 428a, 2943) respecto de un manuscrito de la Matilde de Antonio Marqués, conservado en la BHMM con la signatura 1-74-11, resulta serlo en realidad del volumen de Zavala.

${ }^{69} \mathrm{Al}$ igual que había dicho de El aguador de París, afirma Spell («The theater in Mexico city», pág. 60) que este drama se había representado en el Coliseo de México entre octubre de 1805 y diciembre de 1806.

$7_{0}$ La primera actuación de Marqués para alcanzar el permiso de publicación, por medio de un escrito solicitándolo, data del 27 de marzo de 1803 (AHN, Consejos, 5566-44, s. n.).

71 Jean-Louis-Hubert-Simon Deperthes, Histoire des naufrages, París, Née de la Rochelle, 1788-1789. 
episodio sacado de la realidad más reciente, en el que una gabarra española había sufrido un naufragio en las costas de China, y donde pintaba el escritor las peripecias acaecidas por su tripulación en un primer momento, remitiéndose a un posterior y definitivo colofón de su aventura dentro de la misma colección. Tal suceso debió concitar en mucha medida la simpatía y la intriga en los compatriotas lectores, y hasta el mismo autor se mostraba complacido con la acogida de su trabajo por el público. Quizá satisfecho con eso, y tal vez obstaculizado por la consecución de una nueva autorización especial del Ministerio de Marina, necesaria para llevar a término la continuación y desenlace final de lo acontecido con una embarcación hispana en cumplimiento de una misión en el extranjero, dicha conclusión nunca fue llevada a cabo ${ }^{72}$.

Cerraba Marqués esta colección con otro determinado episodio también ausente en Deperthes, y que puede dar razón de esa su especial sensibilización para con la mujer y para con las dificultades añadidas que su condición le acarreaba, pues se conmueve en dicha aventura con la trágica historia de la india Yarico, quien tras salvar la vida del inglés Inkle, y entregada a su amor por él durante un tiempo, acaba siendo vendida como esclava por su inicuo amante ${ }^{73}$.

En ese mismo período comprendido entre 1803 y 1804, tuvo lugar la apertura de una librería en el n. ${ }^{\circ} 8$ de la calle Jacometrezo de Madrid, por la cual pasaban todas las producciones de nuestro literato, y que comenzó denominándose como Nueva y acabó convirtiéndose en la de «Espejo». Aun suponiendo que su propietario fuera alguien de la familia de Antonio, ignoramos la concreta identidad del mismo. Curiosamente, es denominado en alguna ocasión dicho establecimiento como «de Marqués y de Espejo» (por ejemplo, en la Gaceta de Madrid de 18 de diciembre de 1804, n. ${ }^{\circ}$ 101, pág. 1131, o en la de 8 de enero de 1805, n. ${ }^{\circ} 3$, pág. 32).

El 28 de noviembre de 1803 instó Marqués el pertinente permiso para publicar el Manual literario o catálogo de las obras de ciencias, buenas letras y bellas Artes, modernas en su publicación. El 22 de diciembre se le otorgó dicha licencia para la impresión de la obra, que había de recoger los títulos publicados durante 1803, librerías en las que se expendían, precios, asuntos de que trataban, etc. En las actuaciones conservadas en el $\mathrm{AHN}^{74}$ consta, igualmente, la petición, de

72 La prosecución de Marqués en su mala costumbre de reincidir en los galicismos le será reprochada en el Memorial literario (n. ${ }^{\circ}$ XLVIII, pág. 99) y, sobre todo, incluso burlona y desmedidamente, en El Regañón General o Tribunal Catoniano de Literatura, Educación y Costumbres de 11 de febrero de 1804 (n. ${ }^{\circ}$ 12, págs. 93-94).

${ }_{73}$ Tal relato no era tampoco del todo original de Marqués, el cual mencionaba sus fuentes: «Recopilado todo del Diario de los sabios, del Correo de Cádiz y del Semanario de Salamanca del martes 27 de Mayo de 1800 (t. V, pág. 301).

74 AHN, Consejos, 5566-29, [s. n.]. 
noviembre de 1804, a los mismos fines para ese año, con la novedad de que se encabezaba su denominación como Almanak literario, designación que habría de quedarle de forma definitiva ${ }^{75}$. Morán Ortí sostiene que comparando los cuatro números del Almanak con los anuncios de libros insertados en el Diario de Madrid en el mismo período: «el Almanak acentúa los rasgos de modernización, lo que implica una mayor proporción de libros de Ciencias Positivas y menos de Religión, hecho que también se refleja (y en mayor medida) en la comparación entre las cifras de obras traducidas en una y otra serie» ${ }^{76}$. Un par de años después, aparecerá un aviso en la Gaceta de Madrid (7 de noviembre de 1806, n. ${ }^{\circ}$ 91, pág. 948), probablemente redactado por Marqués, en donde aparte de referir la favorable aceptación de su iniciativa, «por su grande utilidad», animaba a autores y editores a que le remitiesen noticia de sus obras, pero eso sí, manteniéndose fiel a sus puntos de vista económicos, «con porte franco, pues de otro modo no se sacarán de la estafeta».

Dentro de este 1804, Marqués y Espejo tornará a darnos una nueva pieza de teatro, proveniente en origen de una novela de Richardson: Miss Clara Harlowe, drama en tres actos y en verso: suplemento a la historia inglesa del mismo título (Madrid, Imprenta de la Viuda de Ibarra) ${ }^{77}$, que no resulta ser, como alguna vez se ha sugerido, una simple traslación del drama en prosa de 1786 , atribuido a Née de la Rochelle: Clarisse Harlove, drame en trois actes; aunque creemos, como Ada Coe ${ }^{78}$, que posiblemente sí hubo de servirle de inspiración a Marqués dicha versión, y que seguramente la tuvo a la vista a la hora de componer la suya.

Parece ser que con este trabajo Marqués insistía nuevamente en una de las cuestiones que acompañaron durante estos años su carrera literaria: ilustrar y proteger a la mujer. Así se colige de las palabras vertidas en las ediciones de la Retórica epistolar posteriores a la primera, en donde pretendía alertar sobre los peligros de este género de escribir cartas, al que fácilmente podían entregarse algunas féminas, en una práctica que, aun iniciada con fines honestos, era susceptible de degenerar en «el funesto precipicio de su oprobio y perdición». En

75 Aunque ya existía el Almanak mercantil o guía de comerciantes, o el Almanak rural, el nombre elegido pudo suponer un guiño de Marqués hacia la memoria de su admirado Torres Villarroel. Por otra parte, ese segundo número salió en el propio 1804, impreso por Gómez Fuentenebro, y en su pág. 266 figura Marqués como «pensionado por S. M. sobre la Mitra de Sevilla».

76 Manuel Morán OrTi, «El Almanak literario de Antonio Marqués: un perfil de la cultura del libro a principios del siglo XIX», Aportes, 43, XV, 2 (2000), págs. 3-14, pág. 11 b.

77 El Diario de Madrid de 13 de agosto de 1804 (n. ${ }^{\circ} 226$, pág. 923) da cuenta de la aparición del drama, escudando su tardanza en ver la luz, cuando las otras dos grandes novelas de Richardson ya habían sido escenificadas, en «la grande dificultad de ajustarle a las reglas».

78 Ada M. COE, «Richarson in Spain», Hispanic Review, vol. 3, 1 (Jan., 1935), págs. 56-63, pág. 61. 
ese loable propósito, nuestro presbítero mencionaba al autor inglés y, de paso, a sí mismo: «El inmortal Richardson destinó varios tomos para imprimir en el corazón de las damas la importancia de esta máxima a que las persuadimos, remitiéndolas a la lectura de: Miss Clara Harlove [sic], cuya preciosa Historia poseemos ya traducida». Tras este término, traducida, insertaba Marqués una nota al pie con el texto siguiente: «Mi drama en verso, de este mismo argumento, prometido por la nota de la primera edición de esta Retórica epistolar, se publicó en efecto, y se halla en la librería de Navarro, en Valencia, y en el puesto de Sánchez, en Madrid, con otras varias piezas dramáticas del mismo estilo» ${ }^{79}$.

Si la Retórica epistolar fue, como hemos dicho, la obra de Marqués más veces impresa, el Viaje de un filósofo a Selenópolis, corte desconocida de los habitantes de la Tierra, publicada en Madrid, por Gómez Fuentenebro en 1804, ha sido sin duda la favorita de la crítica, y la que más estudios ha concitado ${ }^{80}$. Se trata de un relato fantástico sacado de Le voyageur philosophe dans un pais inconnu aux habitants de la terre (Amsterdam, 1761) de Daniel Jost de Villenueve de Listonay, aunque en «drástica selección operada sobre un original mucho más extenso ${ }^{81}$, otro efecto más, quizá, de la inclinación que sentía nuestro clérigo por Torres Villarroel autor del Viaje fantástico del Gran Piscator de Salamanca, "primera obra en la que un español viajó a la Luna»" ${ }^{82}$.

Hemos de resaltar también la opinión de la Gaceta de Madrid de 21 de diciembre de 1804 (n. ${ }^{\circ} 102$, pág. 1140), puesto que adivinamos encubierta tras ella la pluma de Marqués, con su permanente deseo de resultar útil y entretenido a la par: «obra en que se trata con una juiciosa crítica de los abusos de la educación, de la literatura, teatros, comercio, medicina, y de los de las costumbres en general, de un modo, y por un estilo tan nuevo como entretenido, muy proporcionado para instruir y deleitar ${ }^{83}{ }{ }$.

79 Retórica epistolar, Gerona, Oliva, 1824, pág. 222

80 Por señalar solo dos ejemplos, mencionaremos ahora a Jose Carlos MarTínez García, por su edición del Viaje de un Filósofo a Selenópolis, corte desconocida de los habitantes de la Tierra, Paipérez Ediciones, 2007, con el consiguiente análisis previo en la «Introducción» (págs. 6-27), así como el último trabajo al respecto del que tenemos noticia, llevado a cabo por María Dolores Gimeno PuyoL, «Sobre las virtudes y los vicios en las utopías ilustradas en España: el "hombre de bien” ", Dieciocho, 39, 2 (2016), págs. 255-274.

81 Pedro Álvarez de Miranda, «El viage de un filósofo a Selenópolis (1804) y su fuente francesa», Isaías Lerner, Robert Nival y Alejandro Alonso (eds.), Actas del XIV Congreso de la Asociación Internacional de Hispanistas, Newark (DE), Juan de la Cuesta, 2001, t. III, págs. 43-51 (pág. 46). Acto seguido, el propio Álvarez de Miranda facilita un cuadro sinóptico de las partes que fueron traducidas y las que no.

82 María José Gutiérrez Barajas, «El embajador de la Luna de Emilio Carrere. Ensayo de una novela de ciencia ficción», Castilla. Estudios de Literatura, 4 (2013), págs. 449-468, pág. 452.

83 Además, se indicaban allí los lugares de comercialización: el establecimiento de Gómez Fuentenebro y, cómo no, el de Espejo. El mismo periódico informaba igualmente de los sitios en los que se vendía en 1818 (n. ${ }^{\circ}$ 90, 28 de julio, pág. 748), e incluso en 1821 (n. ${ }^{\circ} 330,19$ de noviembre, pág. 1776b), años en los que según parece todavía seguía interesando el libro. 
De igual modo, resulta muy interesante la conexión establecida por Álvarez de Miranda entre el capítulo VIII: «Biblioteca particular del bello sexo Selenítico», «el único, en toda la obra, que no es traducción de Villeneuve», con cierto empeño por fundar una revista por parte de Marqués y Espejo en los comienzos de ese 1804, empresa que finalmente no vio la luz, lo que, a juicio de dicho investigador, le impulsó a incluir en este libro «parte del material que tenía previsto ofrecer en el frustrado periódico» (pág. 50) ${ }^{84}$.

Y es que, en efecto, el 31 de enero de 1804 había firmado una instancia Antonio Marqués para que el Consejo de Castilla le concediera «licencia para imprimir un papel periódico titulado Lyceo general del bello sexo o décadas eruditas y morales de las Damas ${ }^{85}$ », un intento más por su parte para propagar las luces en el mundo femenino; y ponderaba en su solicitud —a la que adjuntaba el prospecto y los seis primeros números- la importancia de esa clase de publicaciones: «convencido de la utilidad de los papeles periódicos, que tanto han servido siempre para la extensión de las letras, y que por la misma razón los han protegido en todos tiempos los Gobiernos más sabios». Y lo mismo el primer censor, Pedro Estala, que consideraba útil el propósito «si con él las mujeres se aplican a leer y aprender las cosas que les son necesarias para el mejor desempeño de las obligaciones que tienen o pueden tener en la sociedad», que el segundo evaluador, Francisco Vázquez, que también calificaba el proyecto de provechoso, no hallaron nada que impidiera salir a la luz la revista. Sin embargo, el 28 de abril, unos pocos días después del dictamen de Vázquez, una Real Orden prohibiendo nuevos periódicos truncará las intenciones de Marqués ${ }^{86}$.

Tanta exuberancia editorial de D. Antonio pudo resultar causa de un contagio familiar, pues dentro aún de ese año de 1804 le dio también a su hermano Fernando por llevar a la imprenta un libro. Y a tal fin lo presentó para la revisión administrativa el 31 de julio ${ }^{87}$, con una posible alusión a Antonio, pues exponía allí: «que ha creído por el dictamen de personas doctas poder ser de mucha utilidad para el público el adjunto manuscrito intitulado Las noches de Santa María Magdalena». Sin embargo, la censura inmisericorde de Juan Bautista Ezpeleta, que no reconoce ningún mérito a la obra, terminó por destinarla al olvido.

${ }_{84}$ Sobre estos puntos, puede consultarse: Elena de Lorenzo Álvarez, «La biblioteca particular del bello sexo selenítico de El viaje de un filósofo a Selenópolis», en François Étienvre (dir.), Regards sur le Espagnoles créatrices (XVIIT-XX siècle), París, Presses Sorbonne Nouvelle, 2006, págs. 47-60.

85 AHN, Consejos, 5566-59, [s. n.].

86 Dicha resolución es recordada por Lucienne Domergue, «Censura y periódicos», Tres calas en la censura dieciochesca. Cadalso, Rousseau, prensa periódica, Madrid, Gredos, 1981, pág. 78. Sobre el Liceo General del Bello Sexo, puede consultarse Elisabel LARRIBA, «Los periodistas y el derecho a la educación para todos», Cuadernos de Historia Moderna. Anejos, VI (2007), págs. 119-145 (págs. 140 y sigs).

${ }_{87}$ AHN, Consejos, 5566-82, [s. n.]. 
Y así llegamos a 1805, año en el que sorprendentemente no hemos topado con ningún rastro literario de Antonio Marqués. El único indicio de él que poseemos resulta, además, bien tardío, pues data del 30 de diciembre, cuando, en compañía del mentado Fernando, acudió a la escribanía de Jacobo Manuel Manrique a traspasar los poderes otorgados para la administración de sus propiedades en Alberique y Sans a su común hermano Tadeo, abogado de los Reales Consejos, con residencia en Valencia ${ }^{88}$.

En 1806, probó nuestro autor de nuevo a imprimir un periódico, ahora en Valladolid, con el título de El Plausible. Al objeto de alcanzar la aprobación, firmó un escrito en Madrid el 21 de enero de ese año en el que recogía, además de su cualidad de pensionado por S. M. sobre la mitra de Sevilla, la antigua de capellán castrense, así como la de «Escritor público de diferentes obras, en verso y en prosa, como consta por el número del Almanak literario que tiene el honor de presentar a V. Excma.» ${ }^{89}$. Alegaba Marqués que, pese a erigirse la ciudad de Valladolid en una de las más florecientes de España, se hallaba privada de un «Diario por cuyo medio se excite más a su industria, se ilustre con la extensión de las luces que semejantes escritos ofrecen; y se haga notorio el estado actual de su Agricultura, de su Comercio, Ciencia y artes». Y a través de otro escrito con la misma fecha, sacaba a relucir una vez más aquel su veta crematística, puesto que interesaba de la real piedad de $\mathrm{S}$. M. la gracia de franquiciar la mitad del importe que supondrían los gastos de correo del periódico.

Tales peticiones tropezaron, no obstante, con el parecer del juez de imprentas, a la sazón Juan Antonio Melón, quien fundamentó su desfavorable informe de 6 de febrero, complaciéndose — da la sensación de que maliciosamente—en la razón de los cuatro números que el promotor de la idea había adjuntado, y en cuyo trasfondo parece adivinarse un seguimiento de años hacia la obra de Marqués: «En ellos encuentro la mayor insustancialidad, la ligereza francesa, la lengua francesa, la lengua francesa más bien que castellana, las ideas y estilo franceses, y en suma todo francés». Y una nueva carga contra las malas influencias literarias del país vecino: «la corrupción de la lengua, la garrulería y superficialidad francesa, y el estilo de los atolondrados mozalbetes de París», hacen tornar a Melón al tono irónico del principio: «Si el que solicita imprimir este diario no hubiera acompañado dichos cuatro números diría, como otras

88 AHPM, 21 880, ff. 1196r-1197v. Tadeo debía ser unos cuantos años mayor que Antonio, pues lo encontramos residiendo en Madrid en el año 1777 (AHPG, 37 914, poder de José Marqués a favor de su hijo Tadeo, 27 de julio de 1777, f. $55 \mathrm{r}$ y v).

89 AHN, Consejos, 11 285-60, [s. n.]; por otra parte, en AHN, Consejos, 11 287-38, se guarda un escrito de las actuaciones del Liceo General del Bello Sexo y otro de El Plausible. 
veces, que no hallaba reparo en que se le concediese licencia; pero a vista de ellos no puedo dejar de decir lo que siento».

En 1806 publicó Marqués y Espejo los cinco volúmenes de la Elección de viajes modernos, que contiene los sucesos más útiles y agradables, relativos a las expediciones y principales descubrimientos hechos alrededor del mundo, y la descripción de los usos y costumbres de los pueblos, una traslación al castellano de Choix de voyages modernes pour l'instruction et l'amusement des deux sexes, de J. F. André, quien a su vez la había vertido del original inglés de John Adams. Se imprimió la reproducción hispana —que convirtió los dos tomos en 8. ${ }^{\circ}$ de André, en cinco ${ }^{90}$ en 12. - - formando parte de las trece entregas de la Biblioteca Selecta de las Damas (tomos IV-VIII ${ }^{91}$ ). Aunque se omitió en ellos el nombre del traductor, es posible relacionar dicho trabajo — enmarcado una vez más en un proyecto de ilustración de la mujer - con el presbítero alcarreño gracias a la Gaceta de Madrid de 19 de junio de 1807 (n. ${ }^{\circ}$ 52, págs. 625-626), y a la mención que de ella hace Paula Demerson, aunque denominándola Colección de viajes modernos $^{92}$, en una errónea designación del título que ha devenido hoy en día en común. Un toque muy del carácter práctico de nuestro escritor fue el de insertar al final del último volumen una «Tabla alfabética de todos los reinos, provincias, ciudades, golfos, bahías, cabos, ríos, \&. de que trata esta obra», indicando el tomo y página en que asomaba cada uno de aquellos nombres.

Por otro lado, y conforme se echa de ver en las sucesivas Gaceta de Madrid de 17 de junio (n. ${ }^{\circ}$ 50, pág. 520), 18 de julio (n. ${ }^{\circ}$ 59, pág. 616), de 7 de octubre (n. ${ }^{\circ} 82$, pág. 851), etc., en donde se iba anunciando la venta de cada volumen, ya no se mencionaba la librería de Espejo, sino que remitían ahora para su adquisición a la de Fuentenebro, o a la de Alonso; si bien con la marca indeleble del siempre ahorrativo Antonio: «al precio fijo de 10 rs. en esta Corte, pero con un real de aumento en las capitales por razón de los portes». Como de relieve queda plasmado desde el subtítulo: «que contiene los sucesos más útiles y agradables», y en reiteración del objetivo que movió al «célebre John Adams», incidía la Gaceta en ese afán de «instrucción y recreo de la juventud» que había perseguido el autor y que, por ende, había que extender a su traductor español.

90 De los 35 capítulos que componían el primer tomo de su fuente, suprimió Marqués dos de ellos, el IX: «Cruautés barbares des Espagnols dans le nouvel hémisphère», y el xxII: «Thomas Cavendish. Prise d'un riche vaisseau espagnol à Acapulco».

91 El tomo 1. ${ }^{\circ}$ impreso por Fuentenebro y Compañía, y los 12 restantes por Repullés.

92 Paula Demerson, Esbozo de biblioteca de la juventud ilustrada (1740-1808), Oviedo, Cátedra Feijoo / Universidad de Oviedo, 1976, pág. 25. Si bien la equivocación no partió de ella, puesto que, por ejemplo, en la Gaceta de Madrid de 3 de mayo de 1827 (n. ${ }^{\circ}$ 53, pág. 212b) ya se anunciaba como Colección de viajes modernos, de los sucesos más notables y los usos y costumbres de los pueblos, 5 tomos en $12 .^{\circ}$. 
1806 es igualmente el año en que Fernando Marqués, el hermano militar de Antonio, toma cierta decisión familiar que, sancionada ante notario, ha llegado hasta nuestros días, permitiéndonos así señalar algunas posibles concomitancias entre futuras obras de Antonio Marqués y sucesos realmente acaecidos. El asunto fue el siguiente, el 20 de mayo acudió a la notaría el susodicho Fernando, teniente retirado del regimiento de $\mathrm{Toro}^{93}$, «marido y conjunta persona de $\mathrm{D}$. ${ }^{\mathrm{a}}$ María Francisca Estévez», declarando que «antes de realizar su matrimonio dio la referida su mujer a luz una niña en el día veinticinco de Febrero del año pasado de mil ochocientos uno». Como este suceso había ocurrido en Zamora, y la criatura, de nombre Cesárea María del Carmen, se hallaba recogida en la Real Casa de Niños Expósitos, otorgaba poder ahora a favor de un capitán amigo suyo, de aquella vecindad, para que la recogiera en su nombre con sigilo y la trajera con sus padres ${ }^{94}$.

Por lo que hace a 1807 únicamente hemos encontrado un documento referente a nuestro literato. Se trata de un nuevo poder notarial firmado por él y, otra vez, por su hermano Fernando, «residentes al presente en esta Corte», a los consabidos fines de la administración de sus tierras en Alberique ${ }^{95}$, en el despacho del mismo fedatario de siempre, Jacobo Manuel Manrique, quien por cierto, casualidad o no, tenía su residencia en la calle del Espejo (Diario de Madrid, de 18 de setiembre de 1789, n. $^{\circ} 261$, pág. 1044).

La sequía literaria de Antonio Marqués respecto de períodos anteriores parecía iba a tener continuación en 1808, sin embargo, las especiales y fatídicas circunstancias que caracterizaron ese año le empujaron a retomar la pluma para escribir la Higiene política de la España, o medicina preservativa de los males morales con que la contagia la Francia. Este libro fue publicado en Madrid, por Repullés (156 págs. en 12. ${ }^{\circ}$, por el que citaremos siempre en este trabajo), y en Valencia, en la imprenta de Benito Monfort (42 págs. en 4. ${ }^{\circ}$ ), con una ligera variante en su subtítulo: medicina preservativa contra los males con que la contagia la Francia; en ambas tiradas se conserva la condición de Marqués de ser

93 Respecto de Fernando Marqués, en el Archivo General Militar de Segovia (Sección 1. a , legajo M-821), existe la contestación de un oficio remitido por la Capitanía General de Castilla la Vieja, fechada en Zamora el 16 de febrero de 1832, en donde, en relación a una instancia de D. ${ }^{a}$ Francisca Estévez, se dice que ella y su marido habían abandonado dicha plaza en 1804, así como que al presente residía en Madrid con sus hijos, que la sostenían, por cobrar una pensión que no llegaba a los 92 reales.

94 AHPM, 21881, ff. 311r-312v. Sin embargo, algún impedimento debió de existir en la cumplimentación de esa diligencia. Pues dos meses y medio después, el 6 de agosto de 1806, hubo de repetir Fernando el documento, esta vez a favor de su esposa, que se hallaba en Zamora, para que recogiera a la hija de ambos de la mencionada institución en la que se hallaba internada (AHPM, 21881, ff. 374r-375r).

${ }_{95}$ AHPM, 21882, ff. 24r-25v. Por su parte, Morán Orti ya mencionaba este documento en su citado artículo sobre «El Almanak literario [...]», p. 5a, n. 
pensionado de S. M., pero no aparece la de capellán colector en el convento de Santa María Magdalena, aunque como no siempre plasmaba en la portada ese empleo ignoramos hasta cuándo duró en él ${ }^{96}$.

En su estudio sobre la obra, Morange opina que, si bien no había conseguido determinarlo, la edición valenciana posiblemente antecedió a la madrileña ${ }^{97}$. Nosotros, en cambio, creemos justamente lo contrario, y ello porque hasta en cuatro ocasiones $^{98}$ alude el autor a «esta corte», para expresar el lugar donde se situaba al redactar su trabajo. Por lo que atañe a su enmarque temporal, tal y como apunta Morange ${ }^{99}$, probablemente fue escrito el texto hacia el mes de setiembre; y como muy tarde fue terminado en octubre, habida cuenta de las batallas a que se refiere en el mismo: «Baylen, Rioseco, Aragon, Valencia y Gerona» ${ }^{100}$, o a las observaciones con las que encuadraba sus comentarios sobre los horrores de la guerra, contemplados, fiel a su especial sensibilidad por las mujeres, desde una óptica de sufrimiento femenino:

[L]as lágrimas que he visto en sus hermosos ojos, por el espacio de estos cuatro meses, han enternecido mi corazón hasta el punto de desear yo destruir para siempre los motivos de que en lo venidero tengan que derramarlas de nuevo. A esto aspiro únicamente por este papel. Contribuye, pues (hermoso sexo) a realizar mis intenciones muy útiles a toda nuestra nación, y aun de la mayor importancia $^{101}$.

En la «Advertencia» no exhibía Antonio el natural buen humor al que nos había acostumbrado en sus preámbulos, sino que, al contrario, se mostraba en ella teñido de negros presagios. Reconoce que ni sus años ni sus fuerzas le permiten tomar parte en la presente lid, por eso recurre a escribir, y ello con la esperanza, en algún punto arrogante, de que su parecer habría de servir de algo:

96 A este tenor, Catalina GARCía recoge la versión de la pérdida del archivo de la colecturía de «las Recogidas» durante la guerra de la Independencia (Biblioteca de escritores, $301 \mathrm{~b}$ ).

97 Claude Morange, «La sátira de costumbres como artefacto ideológico. En torno a un opúsculo de 1808», Cahiers de civilitation espagnole contemporaine. De 1808 au temps présent, 2 (2015), § 3 [número extra], en red.

98 Antonio Marqués y EsPejo, Higiene política de la España, o medicina preservativa de los males morales con que la contagia la Francia, Madrid, Repullés, 1808, págs. 4, 46, 84 y 125.

99 Morange, «La sátira de costumbres como artefacto ideológico. En torno a un opúsculo de 1808», § 2.

100 Marqués y EsPejo, Higiene política de la España, pág. 19.

101 Marqués y EsPejo, Higiene política de la España, pág. 17. El 31 de octubre anunciaba su venta el Diario de Madrid (dato que ya facilitaba Morán OrTI, «El Almanak literario», pág. 6b), y al día siguiente la Gaceta de Madrid de 1 de noviembre de 1808 (n. ${ }^{\circ}$ 140, pág. 1410) se hará también eco de su publicación, indicando su tamaño: en $12 .^{\circ}$, con lo que solo podía referirse a la edición madrileña de Repullés. 
En este conflicto, por dar algún desahogo a mi espíritu, pensé en tomar la pluma, lisonjeándome con la esperanza de que tal vez en un tiempo en que se devora con harta ansia cuanto sale de la prensa, relativo a los asuntos políticos del día, pudiera yo encontrar arbitrio para contribuir a las necesidades de estado. Estos son los fines y el motivo que sacan a la luz pública esta obrilla, a la que hubiera intitulado mejor: Mi ofrenda a Fernando VII y a su leal Nación ${ }^{102}$.

Recordaba, asimismo, en esa «Advertencia» que sí que había participado activamente en la anterior contienda con Francia: «Ya en la pasada, como buen vasallo, arrostré en ellos [en los Pirineos], por el espacio de cuatro años, los trabajos y riesgos padecidos en honor de nuestras banderas». En esa declaración habla, como se ve, de vasallaje (posiblemente por su relación con Infantado) y de lealtad a las enseñas patrias, pero se omite mencionar al rey, es decir, a Carlos IV. Ese silencio, así como la mucha privanza que su señor, el duque — participante en la conjura de El Escorial y en el motín de Aranjuez-, mantenía con Fernando VII (a quien Marqués ofrece su obra), puede llevarnos a pensar, aunque sin ninguna base documental, en ciertas discrepancias de nuestro presbítero con la política del anterior monarca o con el papel de Godoy, responsables últimos de la desastrosa situación que sufría España en aquellos momentos ${ }^{103}$.

Sea de esto lo que fuere, el caso es que en el ánimo de Marqués parece abrirse un abismo de diferencias entre esta guerra con Francia y la pretérita, al punto de que ahora aboga por renunciar a muchas de las prácticas y modas del país vecino que él había empleado, defendido y preconizado hasta entonces ${ }^{104}$ : «El buen español, de cualquiera clase, condición o sexo debe evitar, a ejemplo de nuestros antepasados, toda correspondencia, imitación o apariencia de ventaja que provenga de los franceses» (págs. 21-22). En este sentido, podría decirse que su mundo cultural se tambalea intensamente. Gómez Imaz, por su parte, observa algunas concordancias entre este canto de la palinodia hacia

102 MARQués y EsPejo, Higiene política de la España, págs. 11-12.

103 En 1808 el duque del Infantado fue nombrado por Fernando VII presidente del Consejo de Castilla y coronel jefe de la Guardia Española, y Antonio Marqués no pierde ocasión en este libro para ensalzar de muy singular manera a su antiguo señor, Pedro Alcántara de Toledo, si bien elude mencionarlo explícitamente: «sin nombrar al ilustre educando, que por fortuna nuestra está hoy en esta Corte, siendo el objeto de nuestras esperanzas en este tiempo de nuestra redención política» (pág. 46). Este término, «redención», puede reforzar la expresada sensación que, según sugerimos, era susceptible de albergar respecto de anteriores errores de bulto en la gobernación del reino.

104 Romera Valero se refiere a él de la siguiente forma: «Era un hombre tan afrancesado que algunos le acusaron de introducir demasiados galicismos en sus traducciones, y es cierto» (Ángel Romera VALERo, «La literatura del siglo xix en Castilla La Mancha. Ensayo de un canon», en Alfonso González-Calero García (coord.), Cultura en Castilla-La Mancha en el siglo XIX, Ciudad Real, Almud, 2012, págs. 15-136, cita en pág. 29). 
todo lo francés con determinados versos de Torres Villarroel que vaticinaban la apropiación de España por parte de Francia; de ahí que realice el siguiente apunte: «El Dr. D. Antonio Marqués y Espejo parece el eco de Villarroel cuando en 1808 publicó el opúsculo satírico contra las costumbres afrancesadas, demostrando cuán arraigadas estaban en ciertas clases, aun después de la gloriosa y triste guerra del Rosellón» ${ }^{105}$.

Por otro lado, y como mera hipótesis suponemos que Antonio Marqués y Espejo, ante la inminencia de la entrada de Napoleón en Madrid al frente de la Grande Armée, tomó la decisión de marcharse a la provincia de Valencia, de donde era originaria su familia, y en la que sabemos que él mismo mantenía posesiones. Allí volverá, según nuestra suposición, a dar a la estampa la Higiene política, impresa ahora en la España libre por Benito Monfort.

\section{Los últimos años en Valencia}

Escritor bastante conocido en el Madrid literario de su época ${ }^{106}$, su figura se nos torna bastante más esquiva en la postrera etapa de su vida, especialmente en el período que va de finales de 1808 hasta 1816, respecto del que carecemos por completo de datos. Siete largos años que además fueron de mutismo editorial, posible consecuencia del enfriamiento y rechazo personal hacia sus fuentes y modelos franceses ${ }^{107}$, así como, desde luego, secuela de la anómala situación por la que atravesaba la patria.

Solo retomamos su pista a partir de 1816, año en el que dio a las prensas dos piezas dramáticas, ambas en la imprenta valenciana de José Ferrer de Orga: La recompensa del arrepentimiento y Amor y virtud a un tiempo ${ }^{108}$. Y otra vez se

\footnotetext{
105 Manuel Gómez Imaz, Inventario de los cuadros sustraídos por el Gobierno Intruso en Sevilla, año 1810, Sevilla, Centro de Estudios Andaluces / Editorial Renacimiento, 2009, pág. 96.

106 Morán Orti en una nómina de autores, en la que inserta su nombre, nos proporciona una buena referencia comparativa, cuando hablando de la imprenta y librería de Fuentenebro enuncia esto: «parece que, entre 1803 y 1808, editó copiosamente por cuenta propia e imprimió obras de autores y traductores entonces de renombre como eran, entre otros, Manuel José Quintana, Bernardo María de la Calzada, José Blanco y Crespo, Juan Nicasio Gallego, Gaspar Zavala y Zamora, Antonio Marqués y Espejo, Vicente Rodríguez de Arellano, José Vargas Ponce o Eugenio Tapia» (Manuel Morán Orti, «La imprenta y librería "Qué fue de Fuentenebro": un modelo empresarial y un programa editorial a finales del Antiguo Régimen», Ayer, La formación de los Estados-naciones americanos (1808-1830), 74, 2 (2009), págs. 165-190 (pág. 170)).

107 Pero, aunque tardó, parece que volvió a retomarlos. Así, Juan Catalina supone que La recompensa del arrepentimiento es un arreglo de una obra francesa (304b); por su parte, Cotarelo señalaba ese mismo país como raíz de La filantropía (pág. 200, n.), y se nos aparenta también bastante posible una ascendencia gala en Anastasia.

108 La primera de ellas probablemente fue compuesta a finales de 1815, pues en la portada del ejemplar impreso se proclamaba que esta pieza había sido representada repetidas veces desde el día cuatro de
} 
nos vuelve a tornar visible, tal vez en 1818, gracias a un par de nuevas composiciones teatrales: La filantropía o la reparación de un delito y Los compadres codiciosos $^{109}$, también en prosa y con las escenas sin numerar, como las precedentes ${ }^{110}$, estampadas igualmente en Valencia, pero ahora en el taller que, aunque de la propiedad de Miguel Domingo, se hallaba regentado en dicha época por su futuro yerno, Ildefonso Mompié ${ }^{111}$. Asimismo, fue impresa en esa misma casa y año la narración titulada Anastasia, o la recompensa de la hospitalidad. Anécdota histórica de un casto amor contrariado, en cuya portada se menciona para el autor la cualidad, ausente en el resto de sus libros, de «beneficiado de la parroquial de Alberique» ${ }^{112}$, indicio, bien que leve, de que este hubiera sido el último publicado ${ }^{113}$.

Ubicadas en distintas localidades de la geografía nacional (Valencia, Sevilla, una ciudad cerca de la frontera con Portugal, Madrid o un pueblo de los Pirineos) estas cinco obras presentan, sin embargo, una serie de rasgos comu-

enero de 1816. Lo hizo también con posterioridad en Madrid, conservándose de ese evento las censuras previas, cuyo permiso fue otorgado finalmente por el teniente de corregidor León de la Cámara Cano el día 28 de mayo de 1816 (BHMM, Tea 1-142,13). Y respecto de la segunda, Amor y virtud a un tiempo, no le fue muy a la zaga a la otra, pues, conforme apuntaba bajo su título en el texto editado, había subido a las tablas a beneficio de determinada actriz en febrero de ese 1816.

109 Para ser sinceros, hemos de significar que nos ha sido imposible manejar ninguno de estos dos textos en su impresión primitiva, pues el de La filantropía que citamos aquí data de 1819 (en una tirada efectuada ya conjuntamente por Domingo y por Mompié, tras haber regresado aquel del destierro en Ibiza), y solo resultaría edición primera (como comúnmente se acepta, aunque quizá por desconocimiento de la fecha de la muerte del autor) si esta obra hubiera salido de forma póstuma. Por lo que atañe a Los compadres codiciosos, la versión utilizada ha sido la de 1826, impresa en Valencia por Ildefonso Mompié, en cuya portada se indica que dicha comedia fue representada en Madrid en ese año.

110 Casi todas ellas, junto con otras suyas anteriores, fueron recogidas por Moratín el Mozo en su catálogo: «Son de don Antonio Marqués y Espejo los dramas siguientes: Miss Clara Harlowe. —La Filantropía, o la Reparación de un delito.— Matilde de Orleim._-Amor y virtud a un tiempo.— Los compadres codiciosos» (Leandro Fernández de Moratín, Catálogo de piezas dramáticas publicadas en España desde el principio del siglo ХVIII hasta la época presente (1823), en Obras de D. Nicolás y D. Leandro Fernández Moratín, Madrid, Rivadeneyra, BAE, 1857, 4. a edición, pág. 333, n. 42).

111 La razón de ello estribaba en la condena penal que, como consecuencia de sus ideas liberales, sufría Miguel Domingo, y que precisamente finalizó en ese año de 1818 (vid. Felipe Rodríguez Morín, «Miguel Domingo: un impresor liberal víctima de la represión fernandina de 1814», en Marieta Cantos Casenave y Alberto Ramos Santana (coords.), La represión absolutista y el exilio, Cádiz, Servicio de Publicaciones de la Universidad de Cádiz, 2015. págs. 167-188, (pág. 186)).

112 Este municipio había sido tierra de sus ancestros; y así nos lo revela Antonio en la dedicatoria (s. n.) que realizó al duque del Infantado en el ya citado El perfecto orador, donde por medio de una nota al pie de su segunda página se apuntaba lo siguiente: «Cosme Marqués (mi cuarto abuelo), Ciudadano inmemorial de las Baronías de Alberique, fue por sus Excelencias Procurador General de Ellas».

113 Nos referimos, claro, a obras nuevas, no a lo que atañe a posibles revisiones o añadidos de ediciones anteriores, como ocurrió, por ejemplo, con la Retórica epistolar, en cuya segunda edición sí que aparece esa designación eclesiástica en Alberique. Resulta, por otro lado, imposible detenerse ahora a valorar la posibilidad, por algún que otro indicio, de que la mencionada Anastasia hubiese sido redactada, al menos en parte, unos años antes. 
nes $^{114}$. En todas ellas la anterior preocupación por el progreso en la mujer, que había guiado una buena parte del trabajo de Marqués, se ve en cierto modo eclipsada por dos temas recurrentes, como de ello dan testimonio algunos de sus títulos: el cobijo que ha de darse a quien lo ha menester y, sobre todo, la dicha inefable que deviene del arrepentimiento o de la recuperación de la senda perdida $^{115}$. Y como sabemos de su paso, como capellán, por «las Recogidas», así como que su hermano Fernando, teniente del ejército, reparó la acción de mantener alejada durante unos años a su hija extramatrimonial, no podemos sustraernos a establecer un nexo entre estas últimas elaboraciones de su minerva y varios elementos propios de su biografía.

En esa misma intención, hemos de dejar constancia de al menos algunos apuntes, como por ejemplo la condición de militar del padre de Anastasia, en la novela Anastasia, o la recompensa de la hospitalidad, quien, aun sin quererlo, deja desamparada a su hija ${ }^{116}$, o de Eduardo Pimentel, en La filantropía o la reparación de un delito, capitán destinado en Zamora (igual que el hermano de Antonio Marqués), que hubo de huir, muchos años atrás, de la justicia, dejando abandonados a sus dos hijos (uno de ellos llamado Fernando), y a la madre de ellos, soltera, que en el tiempo durante el que transcurre la acción se muestra como un modelo de hospitalidad, dando cabida en su posada a todo el que lo necesita. Igualmente, en Los compadres codiciosos uno de los protagonistas es capitán, y de nombre Fernando, aunque su padre hubiese querido que estudiara para abogado en la Universidad de Alcalá (como creemos que así hizo Tadeo, uno de los hermanos mayores de Antonio) ${ }^{117}$. En La recompensa del arrepentimiento, el joven Julián, uno de los personajes centrales del drama, se halla instalado en la rica casa de sus protectores desde el punto de su nacimiento. Y en

114 Gracias principalmente a la Gaceta de Madrid, advertimos de la venta de La recompensa del arrepentimiento y de Amor y virtud a un tiempo, además de en Valencia, en Madrid y Barcelona, así como la de Anastasia en Valencia y en Madrid.

115 En el terreno religioso tales propuestas conducen al perdón divino, con el consiguiente retorno a la vida de la gracia y a la dicha inmensa por ella producida: «Y tú debes, por tu parte, esperar con tu arrepentimiento desciendan sobre ti las bondades eternas de un Dios infinitamente misericordioso» (Anastasia, pág. 146). Incluso, alguna apreciación experimentada en otros diversos campos de la existencia humana conserva ese aroma de paz espiritual de quien recobra la calma tras haber vivido durante años en zozobra por su alma; quizá por eso D. Simplicio cierra Los compadres codiciosos (pág. 60) explicando que si se siente feliz aquel que disfrutó de una vida tranquila en su lugar de origen, «lo es infinitamente más el que vuelve a encontrar tan dulces bienes después de que él había creído que los había perdido para siempre».

116 En ese concreto aspecto se desmarca de nuevo sobre los demás textos el de Anastasia, en donde el propio Antonio Marqués actúa como personaje dentro del relato. Para un mayor conocimiento de esta obra, vid. Ana RuedA, Cartas sin lacrar, págs. 352-360, o «Housing the Enemy: Non-competing Moral Demands in Marqués y Espejo's Anastasia (1818)», The Workshop, n. ${ }^{\circ} 3$ (2015), págs. 23-32.

117 En lo tocante a este tema de la milicia, no podemos olvidarnos de Paulino, sargento de inválidos en Amor y virtud a un tiempo, que anduvo destinado en los Pirineos, exactamente igual que el autor de la obra. 
esos mismos términos también de estancia en acogida, Nicasia, protagonista de Amor y virtud a un tiempo, permuta la casa de D. ${ }^{a}$ Felipa por la de D. ${ }^{a}$ Florencia.

Por otro lado, Antonio Marqués y Espejo con tantos años de servicio como sacerdote, prestando el auxilio de la confesión a muchos semejantes contritos, seguramente atendió el tema del arrepentimiento como objeto de una especial y profunda reflexión en esta época final en que veía su vida retirarse, («cuánta necesidad tenemos todos de indulgencia» ${ }^{118}$ ). Tal vez por eso, en estos cinco títulos finales se observa la rectificación de muchas de las actitudes previas de sus criaturas de ficción, las cuales, a partir de unos rígidos planteamientos, suelen mudar hacia otros más permisivos al paso que comprueban cómo esa deriva procura la felicidad de quienes los rodean. En ejemplo de ello, traemos una sola frase del final de La filantropía (pág. 59), que bien podría valer como lema del pensamiento del escritor: «Las sinrazones de un momento nada suponen cuando son reparadas».

Acaso otro indicio de que el final de Marqués no parecía ya asunto muy lejano, lo constituye el distinto enfoque con que acomete la cuestión del dinero, o, por mejor decir, de su utilización: «Y pues que después de la muerte no pueden gastarse las riquezas, no será malo que disfrutemos algo de ellas en vida» ${ }^{119}$. Igualmente, recapacita sobre la función social de los bienes: «no ignoro que se debe dar cuenta al público del uso que uno hace de sus riquezas. El que las entierra las inutiliza; es un mal patriota» ${ }^{120}$; «jamás me he creído que la industria de un comerciante fuese propiedad suya: he pensado por lo contrario que debía esta industria emplearse en el bien de la sociedad» ${ }^{121}$.

En ese mismo capítulo de reivindicaciones sociales, es también interesante el negocio de las relaciones entre amos y señores, que suelen ser de cercanía o incluso de amistad, como la de D. ${ }^{a}$ Manuela con su criada: «Elena, tú me amarás siempre; así me lo has prometido» (La recompensa del arrepentimiento, pág. 16b); aunque este aprecio mutuo que generalmente sienten dichos personajes de sus obras no le impide al autor lanzar, de vez en cuando, su crítica, por boca de algún sirviente, contra el elemento poderoso del binomio: «nos llaman enemigos forzosos, se nos mira como a tales; nos tienen generalmente por pura necesidad, sin amor, ni ley, hasta que viene nuestra vejez [...]. Entonces [...] se nos ajusta la cuenta, nos despiden de su casa $[\ldots]{ }^{122}$.

118 Antonio Marǫués y Espejo, La recompensa del arrepentimiento, Valencia, José Ferrer de Orga, 1816, pág. 23b.

119 Antonio Marqués y Espejo, Los compadres codiciosos, Valencia, Miguel Domingo, 1818, pág. 59.

120 Antonio Marqués y Espejo, Los compadres codiciosos, pág. 56.

121 Antonio Marqués y Espejo, La recompensa del arrepentimiento, pág. 7b.

122 Antonio Marqués y Espejo, Amor y virtud a un tiempo, Valencia, José Ferrer de Orga, 1816, pág. 4a. No resultará ocioso recordar al efecto que, en La filantropía, un modesto barbero pretenderá batirse en duelo con un caballero militar, a causa de un bofetón que, imbuido por un espíritu de superioridad social, 
Y trascendiendo del mundo de los personajes hacia el de su creador, ha de subrayarse el hecho de que el año 1818 fue el de su muerte. Frente a la extendida opinión que postergaba tal suceso a partir de 1826, situándolo a menudo en 1828, probablemente por haber tenido lugar la reimpresión de algunos de sus libros en esas fechas con la misma portada que en la primera edición, un documento notarial nos viene a despejar las dudas, y ello por una cuestión de azar; pues habiendo fallecido Marqués y Espejo en Valencia, en cuya diócesis fueron destruidos durante la Guerra Civil casi todos los libros parroquiales de bautismo, matrimonio y defunción, resultó ser la casualidad la que nos permitió hallar en un legajo de la escribanía de Antonio Jacques Furió la fuente de la que se puede obtener dicha información.

Así, en efecto, en un poder otorgado el 30 de noviembre de 1818 por el impresor y librero Mompié (que en aquel tiempo parece que alternaba el nombre de «Alfonso» con el de «Ildefonso») a favor de Bartolomé Manuel Caro, del comercio de libros de Sevilla, sabemos que Antonio Marqués y Espejo, vecino de Valencia, debía al referido Mompié «más de mil reales [de] vellón, procedente de dinero que le prestó graciosamente, y consecuentemente a su fallecimiento» reconvino «el Otorgante a D. Tadeo y D. ${ }^{a}$ Ana Marqués y Espejo, hermanos y herederos de dicho difunto, para que le solventasen la mencionada suma».

$\mathrm{Y}$ en definitiva, los hermanos de Antonio alcanzaron el siguiente acuerdo con Mompié:

[Q]ue todo su crédito quede reducido a mil reales de vellón, y que estos los cobre dicho D. Alfonso Mompié de los atrasos que le está debiendo la Mitra de Sevilla al mencionado difunto Dr. D. Antonio Marqués y Espejo, por la pensión que este disfrutaba sobre la misma, como igualmente las costas ocasionadas sobre dicho Particular en el Juzgado del Señor D. Josef Manuel Rodríguez Valdenavarro, del Consejo de S. M., su Ministro en la Sala del primer de esta Real Audiencia y de Provincia de la misma» ${ }^{123}$.

\section{Conclusiones}

A la vuelta de todas estas consideraciones, creemos que la principal seña de identidad de Antonio Marqués y Espejo posiblemente fue la de una fuerte

le había propinado este. Al final queda suspendido el desafío porque el oficial se retracta y reconoce como valiente a su oponente.

${ }^{123}$ Archivo del Reino de Valencia, Protocolos Notariales, 6291, ff. 333r-334r, f. 333r. 
empatía hacia aquello que sentía cercano o, de otra suerte formulado, la capacidad de su entorno para influir en su carácter. Por eso creemos que los apuros económicos sufridos cuando carecía de oficio y de beneficio, que hasta le impedían vestir con decencia, rigieron mucha parte de su existencia posterior. Él mismo nos lo revelaba sin tapujos en alguna de sus obras, según hemos comentado, las cuales solían ir, por lo general, dirigidas a un público amplio que asegurase una buena venta. En persecución de dicho éxito comercial, no escatimará en emplear una amplia gama de recursos que, aún en el día de hoy, pudieran parecer modernos: lanzamientos editoriales durante un tiempo a más bajo precio, ofertas, descuentos, redacción personal de los anuncios en la prensa, y hasta firma de ejemplares; amén de otro tipo de tretas, tales como introducir la figura de un presunto editor haciendo ver que este había escogido al traductor más adecuado, es decir, a él mismo, o insertando algún episodio que atrajese al destinatario en el primer volumen y lo mantuviese atrapado y en vilo durante el resto de tomos de la colección.

Insistiendo en esa misma idea de inmersión emocional en el contexto que le rodea, ha de remarcarse que su residencia en Francia y los estudios llevados allí para consagrarse como sacerdote determinaron en gran medida su futuro como escritor, siendo así que a la inmensa mayor parte de sus frutos literarios se les puede rastrear un origen en el país vecino. Por otra parte, conjeturamos que su nombramiento como capellán en un centro de recogida de mujeres en Madrid pudo condicionar la perspectiva que tenía del ámbito femenino, llamándolo, quizá, a una especial preocupación por atender su ilustración, ya desde varios de sus libros, o ya mediante un intento de actuación más constante y regular a través de una revista periódica; aunque finalmente este proyecto no fue dado de paso por la autoridad.

$\mathrm{Ni}$ que decir tiene que, en esa tan poderosa capacidad de impregnarse de percepciones de su realidad más inmediata, tuvo que gozar de primordial papel su círculo más próximo. Sin embargo, la escasez de datos respecto de la persona de Antonio Marqués se hace extensiva, incluso en bastante mayor medida, a lo que se refiere a su familia y amigos; ahora bien, de los pocos rasgos que de ellos conocemos, especialmente relativos a su hermano Fernando y a las circunstancias de una hija suya nacida antes de contraer matrimonio, sí que parece que puede rastrearse una huella en su obra, según más atrás hemos apuntado.

Todo este apego por lo cercano se vio puesto en peligro de forma violenta con la invasión francesa. El continuo sufrimiento, secuela de la guerra, que veía a su alrededor, del que se hizo eco en Higiene política de la España, fue traducido por Marqués en rabia contra las modas y costumbres de ese país; y deducimos que tal extremo derivó en una crisis profunda de sus ideas, a tenor de 
la dependencia que sentía por las letras galas. Siete años, posiblemente, tardó en restañar tales heridas, puesto que no poseemos señal alguna de su vuelta al oficio de escribir antes de fines de 1815. De ese breve período hasta su muerte en 1818, apenas sabemos nada de él, más allá de colegir de sus escritos un ansia acentuada por la reconciliación, el perdón y por la dicha inefable de quien vuelve a casa y, arrepentido, comienza una vida nueva.

No fue Antonio Marqués y Espejo, desde luego, ningún genio de las letras hispanas, pero sin embargo suplió esa carencia de talento con un afán enorme por divulgar el saber entre sus contemporáneos, envolviendo las más de las veces la parte árida del conocimiento en una capa amena con la que procuraba, a la par que el suyo, económico, el enriquecimiento cultural del destinatario. En este campo, su tarea principal consistió en traer a la lengua castellana muchas de las obras que se celebraban en Europa, especialmente en Francia, contribuyendo así, como buen ilustrado, a la educación del público que las leía. En dicho menester no se limitó a transcribir mecánicamente de su fuente, sino que, como bien apuntaba algún periódico coetáneo, ofrecía un recreo literario de la misma; dicho de otra forma, componía «traducciones-adaptaciones ${ }^{124}$ ».

Además, pasando por encima de los no escasos galicismos con que afeó sus libros, y juntamente con la similar tarea de otros muchos colegas traductores (bastantes de ellos eclesiásticos, como él ${ }^{125}$ ), resulta indudable que cooperó con sus textos a la modernidad de la nación, haciendo que su literatura fuera, como dice Menéndez Pelayo, «cada día más europea y cosmopolita» ${ }^{126}$.

124 Así las denomina Martínez García, Viaje de un filósofo a Selenópolis, pág. 7.

125 Francisco LAFARGA, «sin agotar la nómina», aporta 22 nombres, en «Clérigos traductores y traducción clerical en el siglo XvIII», Roberto Fernández y Jacques Soubeyroux (eds.), Historia social y literatura. Familia y clero en España (siglos XVIII-XIX), Lleida, Ediciones Milenio / Universitat de Lleida / Université de Saint-Étienne, vol. 3, págs. 83-92 (págs. 88-89).

126 Marcelino Menéndez Pelayo, Historia de las ideas estéticas en España, Enrique Sánchez Reyes (ed.), Santander, Aldus, S.A. de Artes Gráficas, 1947, t. III, pág. 395. 